\title{
Proč nestudovat náboženství: K sociologickému uspořádávání skutečnosti
}

\author{
Why Not Study Religion: On the Sociological Ordering of Reality \\ Milan Fujda
}

\begin{abstract}
In this paper I argue that the concept of religion, or more precisely the whole conceptual structure (composed of interrelated concepts like secular, sacred, rational/irrational, natural/supernatural, science, politics, etc.) surrounding it, is a significant hindrance to the analysis of exactly those things which we want to analyse in the sociology of religion, with results that are theoretically significant for the wider field of sociology. I demonstrate why and how some sociological attempts to bypass such complications by means inherited from the classical theorists fail, and show the importance of the so-called symmetrical approach to make this sociology theoretically relevant again. Such sociology, however, will no longer be sociology of religion. The concept of religion as an analytical category, as I demonstrate, is not compatible with the symmetrical approach.
\end{abstract}

KEYWORDS Émile Durkheim, sociological theory, religion, secularization, modern society, symmetrical approach, modest sociology

\section{Úvod}

Inspirací pro vznik tohoto textu se stala brněnská přednáška britské socioložky Grace Davieové u př́ležitosti českého vydání knihy Výjimečný př́pad Evropa (Davieová 2009). ${ }^{1}$ Grace Davieová ji otevřela prezentací tři fotografií: jedna byla výjevem rituálního tělesného sebepoškozování, k němuž dochází během oslav velikonočního Svatého týdne na Filipínách, druhá odkazovala ke kulturnímu a politickému významu islámu v současné Evropě prostřednictvím zobrazení britské policistky zahalené do hidžábu, poslední měla ukázat význam křest'anství ve Spojených státech amerických prostřednictvím scény z letničního shromáždění. Cílem této obrazové prezentace bylo ilustrovat význam náboženství v dnešním světě a přejít k diskusi o důvodech, proč sociologie, v podobě teorií sekularizace, selhala ve svých analýzách role náboženství v moderních společnostech a proč by dnes měla problematiku

Sociální studia. Katedra sociologie FSS MU, 3/2013. S. 13-43. ISSN 1214-813X.

1 Text vznikl v rámci projektu „Současná kritika pojmu náboženství a její teoreticko-metodologické důsledky" podpořeného z Fondu děkana FF MU (MUNI/21/FUJ/2011). Autor děkuje recenzentům Sociálnich studii za podnětné výhrady, jejichž zohlednění, jak doufá, přispělo ke zvýšení kvality textu. 
náboženství otevírat nejen jinak, ale také s větší vážností, než činila doposud. Jinými slovy ukázat, proč by se náboženství mělo stát jedním z ústředních problémů soudobé sociologie.

Cíl předkládaného textu je opačný: chci v něm demonstrovat, že právě tematizace náboženství představuje překážku porozumění tomu, co považuji, stejně jako Grace Davieová, za důležité. Touto formulací se již snažím naznačit jednu podstatnou věc: nebudu tvrdit, že to, čemu se snaží sociologové náboženství přijít na kloub, nestojí za sociologický zájem. Přesně naopak. Ovšem právě proto mě netěší, že si cestu k porozumění tomuto typu problémů systematicky znemožňujeme lpěním na konceptu náboženství a s ním na celé konceptuální struktuře, která nám řadu zásadních věcí zakrývá. Jinými slovy, znepokojuje mě samozřejmost, s níž se předpokládá, že výše uvedené výjevy z lidského života lze nejlépe objasnit v rámci teoretické perspektivy, $\mathrm{v}$ níž se automaticky počíta $\mathrm{s}$ tím, že nějakým způsobem patří $\mathrm{k}$ sobě a že tím, co je spojuje, je to, že jsou projevem něčeho, co se nazývá náboženstvím.

Pro začátek bych k nastínění problému využil také několik obrazů. Pavlu, Suri a Alem² spojuje to, že muslimský šátek hraje $\mathrm{v}$ jejich životech zásadní, u každé z nich ale odlišnou roli. Zatímco Pavla, původem Kurdka, jež vyrůstala v Česku, objevila jeho význam během svého studia na vysoké škole, kdy začala objevovat také vlastní muslimskou identitu, Íránka Suri naopak šátek z hlavy sundala během svého studia na indické univerzitě. Samozřejmě že po návratu domů se každodennímu zakrývání vlasů pod černý čádor nevyhne. Zatím si však může užívat liberálnosti univerzitního kampusu v indickém Púné. Alem je z Etiopie a svůj slušivý šátek, doplňující modré džíny a bílou blůzku, nosí i v liberálním indickém univerzitním kampusu; navzdory tomu, že její křest’anské etiopské spolužačky dobře vědí, jak rafinovaně využivat oděv k odhalování ladných tělesných tvarů, což tak vzrušuje jejich potenciální nápadníky. Muslimka Alem šátkem zdůrazňuje především své velké kulaté černé oči a styl oblékání jejích spolužaček ji ničím neoslovuje.

Je-li šátek, jako znak jednoho náboženství, tím jediným, co má spojovat britskou policistku s filipínskými kajícníky, má tedy náboženství jako „faktor“ zjevně velmi protikladné efekty, a to dokonce i jen tehdy, když se omezíme na pokrývky hlavy islámských žen. Proč by ale tak odlišné věci jako konformita s domácí tradicí, identita muslimky v ne-muslimské zemi a možnost aspoň dočasně uniknout svazujícímu oku všudyprítomné íránské policie měly být a priori tematizovány jako otázky náboženství?

Na pozadí této pochybnosti chci prozkoumat dva okruhy problémů. Ten první lze vymezit otázkou, na základě čeho jsou v tradici sociologie náboženství (a religionistiky) určité, velice rozmanité projevy lidského jednání subsumovány pod společnou kategorii „náboženství"; jak je s touto kategorií, jakožto kategorií analytickou, nakládáno a jaké to přináší důsledky. Okruh druhý lze vymezit otázkou inverzní: Na základě jakých předpokladů a s jakými důsledky jsou uvedené projevy jednání oddělovány od jevů jiného druhu a vykládány v rámci jiné teoretické perspektivy? Co vlastně přesně děláme, když zacházíme s „,náboženstvím“", jakou povahu tyto operace mají, co způsobují a jak se etablovala ona samozřejmost, s níž je provádíme?

2 Všechna zde uvedená dívčí jména byla $\mathrm{v}$ zájmu anonymizace změněna. 
Tato otázka má samozřejmě zásadní implikace i pro naše tázání po sekularitě. Jak totiž ukázal Timothy Fitzgerald (2003), náboženství ve vědeckých analýzách obvykle nefunguje jako nezávisle vymezený pojem, ale jako párová kategorie k sekulárnímu, přičemž ideologická účinnost (a analytická problematičnost) jeho užívání spočívá v tom, že hranice mezi sekulárním a náboženským je neustále svévolně posouvána podle toho, co se autoři snaží doložit. Směřuje-li dnes sociologické uvažování více k zájmu o povahu sekularity, jedná se o posun jistě užitečný. ${ }^{3}$ Jeho teoretické možnosti jsou ale, vzhledem k výše uvedenému, velmi omezené. Již názvem tohoto textu se snažím naznačit, že za teoreticky přínosnější považuji otevírat přibližně ty problémy, které sociology náboženství zajímají, zcela mimo rámec vymezený pojmy náboženského a sekulárního. Zároveň bych rád aspoň trochu naznačil, jakých principů je možné se při takové snaze držet.

Tuto analýzu otevřu reflexí již zmíněného textu Grace Davieové. A to proto, že se chci vyhnout nařčení ze strefování se do strašáků do zelí. Problémy, jež budu otevírat, totiž nejsou nijak nové, každý o nich už někdy slyšel, ví o nich. Co mě spíš znepokojuje, je to, že tato znalost nemá žádné praktické důsledky. Náboženství odmítá ze sociologických analýz zmizet navzdory veškeré dekonstruktivní práci posledních cca čtyřiceti let. Jedním z důvodů je pochopitelně to, že nemáme čím jej nahradit. Problém je o to palčivější, že, jak se pokusím ukázat, s pojmem náboženství potenciálně neopouštíme jednu marginální kategorii analytického myšlení, ale spíš celou komplexní pojmovou strukturu. Její negativní teoretické implikace jsou mnohem důležitější, než jaké by měl jeden problematický pojem. Právě proto chci problémy, které mě trápí a které jsou vzájemně bohatě provázané, rozebrat na konkrétních př́padech, ve vzájemných souvislostech a s jejich konkrétními praktickými důsledky. Následující text lze patrně označit za teoretickou studii, byl bych však radši, kdyby tak docela chápaný nebyl. Mnohem více mi totiž jde o maximálně konkrétní praktickou ilustraci problémů, které vytváříme, když sociologicky „děláme náboženství“.

\section{Pragmatika analytické kategorie „náboženství”}

Kniha Grace Davieové Výjimečný připad Evropa jako by v neobyčejně koncentrované podobě zosobňovala mnohé naděje i bezvýchodnosti sociologie náboženství. Tím, co mě na ní v tuto chvíli především zajímá, je způsob nakládání s kategorií náboženství, pro niž je př́značné, že se v textu vyskytuje, jakožto zdánlivě analytická kategorie, hojně. Slovní spojení obsahující „,náboženství“ zahrnují takové výrazy jako „náboženské aktivity“, „vzorce náboženských aktivit“, méně/více/jinak „náboženští lidé“, „nekřest’anská náboženství“, „,náboženský prvek“, „,politická“ a „,náboženská moc“, „náboženské poměry“, „náboženské dědictví", „náboženský život“, „náboženská víra“ - dokonce její „,mystičtější stránky“ -, „,indikátory náboženství“, „ukazatele náboženské víry“, „náboženská praxe“, „náboženské chováni'“, charakter „nábožensky založeného obyvatelstva“, „náboženské menšiny“, „židovsko-křest’anské náboženstvi““, „,náboženská hnutí“, rysy „,evropského náboženství“,

Jeden velice sofistikovaný způsob, jak tematizací sekularismu formulovat otázky umožňující myslet mimo hranice ustavené pojmem náboženství, rozvrhl intelektuál arabského původu dlouhodobě kritizující nakládání s islámem v západní sociálněvědné tradici Talal Asad (2003). 
„náboženský pluralismus“, „náboženská vitalita“, „,raison d'être náboženství“, „náboženská pamět"“, „náboženská existence“, „zástupné náboženstvi““, „náboženská inspirace“, „globální náboženskost“. Co činí aktivity, lidi, jednání, víru, praxi, pluralismus atd. „náboženskými“, nelze zjistit, pokud žádáme konkrétnější a korektnější odpověd’ než: „náboženství“.

Tyto bohaté výrazové variace mají nicméně do jisté míry identifikovatelnou tř́́du denotátů: statistická čísla týkající se návštěvnosti kostelů, účastí na bohoslužbách, deklarované př́ślušnosti k církvi, účasti na konkrétních významných církevních rituálech, jako jsou křty, svatby a pohřby, a souhlasu s „náboženskými“ přesvědčeními artikulovanými v dotaznících (Davieová 2009: 17). Neznamená to, že by Grace Davieová byla zcela spokojena s tím, že definici předmětu svého bádání nechává na úřednících př́slušných ministerstev, matrikářích a tvůrcích dotazníků pro mezinárodní statistická šetření. Zejména tehdy, když se zabývá otázkami artikulace identit přistěhovalců, naráží na problémy vycházející z toho, že sociologické nástroje činí statickými výrazně proměnlivé kategorie, a neumožňují proto vhodně postihnout rozličné aspekty „celoživotního hledání“. Dostupná data jí navíc naznačují, že se děje ještě něco jiného, možná velice zajímavého, ale nelze zjistit co. To je odvrácená stránka toho, že jediná mezinárodní data, jež je možné produkovat $\mathrm{v}$ dostatečné míře, vychází z jistého minimálního, teoreticky zcela nezdůvodněného (jakkoliv prakticky pochopitelného) konsensu o tom, co jsou „náboženské“ aktivity, př́slušnosti, postoje, hodnoty.

Proto také situace ve Výjimečném př́padu Evropa začíná být zajímavější v oblastech, jako jsou Latinská Amerika, Afrika a Asie, pro které data bud' chybí, nebo výrazně protiřečí očekáváním vycházejícím z narativů sekularizace ${ }^{4}$. Davieová proto $\mathrm{v}$ jim věnovaných pasážích v mnohem větší míře kombinuje hrubé kvantitativní ukazatele s dílčími poznatky podrobnějších kvalitativních studií. V kontextu Latinské Ameriky tak otevírá např́klad zajímavou problematiku propojení misie letničních hnutí s chudobou a alkoholismem (Davieová 2009: 74). Načrtává mnohovrstevnatý obraz, v němž se církevní aktivita, osobní a kolektivní identita, ekonomická situace a rodinné soužití vzájemně propojují a, podle mého soudu, odkrývají v náznacích řadu zajímavých sociologických problémů právě díky tomu, že rozrušují představy o náboženství jako specifické, jasně vymezitelné oblasti lidského jednání.

Zjednodušeně lze předkládané analýzy shrnout následovně: chudí v sociálně vyloučených lokalitách, mnohdy závislí na alkoholu a v situaci ekonomické nejistoty, se angažují v exkluzivistických letničních sborech, které jim umožňují nabýt nového sebevědomí prostřednictvím členství ve vyvoleném společenství, jež navíc sociálně oceňuje odpovědnost a střídmost (Davieová hovoří o „askezi“). Zprostředkovává jim pevný řád a autoritativní vedení, což dohromady s předchozím vede ke stabilizaci rodinných vztahů, mnohdy i řešení problémů $\mathrm{s}$ alkoholem a $\mathrm{k}$ narovnávání rodinných rozpočtů. Rostoucí míra sociálních jistot a zlepšení životních podmínek je pak důsledkem pomalu strádaných úspor. Tento vývoj událostí je prostřednictvím křest’anské symboliky interpretován jako zázračný výsledek

$4 \quad$ Výraz „narativy sekularizace“ zde používám v návaznosti na argumentaci Romana Vida v knize Konec velkého vyprávěni?. Vido zde upozorňuje, že lze těžko hovořit o „,klasických teoriích sekularizace“, které by bylo možno potvrdit či vyvrátit. Podle jeho soudu lze smysluplně mluvit jen o „sekularizačním paradigmatu“ nebo o „sekularizačních narativech“, přičemž oboje, to je podstatné, je ze své podstaty nevyvratitelné (Vido 2011: 10). 
spasitelské role Krista, což potvrzuje představu vyvolenosti společenství, dosvědčuje správnost zvoleného řešení předtím tíživé životní situace a do jisté míry umožňuje další vzestupnou sociální mobilitu (Davieová 2009: 81-93).

Na této záležitosti je mimo jiné zajímavé, že na analogické sepětí chudoby, konverze, přijetí ze strany exkluzivního společenství, získání nové sebeúcty a zlepšení ekonomické situace v souvislosti nejen s letničními hnutími poukázal třeba i Tomáš Hrustič $(2009,2010)$ ve svých studiích o konverzích marginalizovaných východoslovenských Romů. To lze vnímat jako jednu ze známek toho, že jde o nosný sociologický problém, jehož řešení může vést možná nikoliv k velmi překvapivým, ale přece jen cenným interkulturně empiricky zakotveným poznatkům. Jako takový ale tento problém nemá mnoho společného s náboženstvím a sekularizací, což je oblast, do níž ho zbytečně zavádí Grace Davieová (i samotní autoři a autorky, z nichž vychází).

Z nejasných - a podle mého i principiálně neobhajitelných - důvodů zatěžují tito autoři své analýzy nadbytečným konceptem náboženství, který k objasnění uvedeného mechanismu řešení tíživé životní situace nepřidává nic navíc. Davieová dokonce hovoří o „náboženských faktorech“ (Davieová 2009: 78), kterými ale nemíní nic z toho, co v předchozím odstavci bylo řečeno a co by mohlo odhalovat nějaké „hmatatelné“ pưsobení, ale odkazuje jen ke standardnímu kvantitativnímu indikátoru v podobě členství v církvi. Členství v církvi zde však zjevně nic neindikuje, protože $\mathrm{v}$ př́ípadě církve katolické, zmiňované ve stejných pasážích, se nic podobného neděje. Pokud už by tedy šlo o členství v církvi, tak jde především o členství v církvi určitého typu a mnohem spíš jde prostě o společenství, které musí splňovat řadu dílčích charakteristik, aby celý proces fungoval. V Hrustičových případech např́íklad k vzestupné sociální mobilitě ani $\mathrm{k}$ dlouhodobější účasti na aktivitách církve nedochází, necítí-li Romové plné uznání a důvěru ze strany bílých „souvěrců“. To zní jako „faktor“, který skutečně zakládá nějaký významný rozdíl. Těžko ale říct, proč by měl být chápán jako faktor „náboženský“".

Charles Wright Mills tvrdil, že:

„Metoda“ souvisí především s tím, jak klást otázky a dávat na ně odpovědi a být si při tom alespoň trochu jist, že odpovědi budou mít více či méně trvalou platnost. „Teorie“ souvisí především s tím, jak věnovat soustředěnou pozornost používaným termínům, zejména stupni jejich obecnosti a jejich logickým vztahům. Hlavním účelem je v obou př́ípadech dosáhnout jasné koncepce a úsporné procedury. (Mills 2008: 131, kurzíva MF)

Ve výše uvedeném prŕpadě pojem náboženství přináší pravý opak toho, co lze označit jako „jasnou koncepci a úspornou proceduru“. Jakožto reprezentace nějakého zdánlivého faktoru navíc v uvedených analýzách spíš zakrývá, než zviditelňuje podstatné působící skutečnosti.

Náboženství je v uvedených popisech vydáváno za aktéra (tj. působící element), ale přitom nepůsobi vůbec nic. Nepřináśí žádnou změnu, nezpůsobuje žádný empiricky vykazatelný rozdíl a nevstupuje do žádného jiného vyprávění, než je vyprávění vědců, již mají potřebu jej do něj vložit ještě poté, co bylo už vše vysvětleno. Pravda je, že takový postup není sociologii neznámý a podle Bruno Latoura vychází ze zvláštní povahy „sociálního vysvětlení“, jež podle něj především vůbec není vysvětlením. Místo toho, aby toto vysvětlení 
ustavilo nějaké spojení mezi dvěma entitami, stává se často to, že jedna entita je nahrazena druhou. [...] Stává se to v situacích, kdy je komplexní, jedinečné, pestré, mnohočetné a originální vyjádření nahrazeno jednoduchým, homogenním, banálním a víceúčelovým termínem pod záminkou, že to druhé vysvětluje to první. [...] Zatímco jiné vědy doplňují k jevům př́íiny, tak sociologie je možná jediná, jejíž ,,přičiny“ hrozí podivně tím, že jevy, jež mají vysvětlit, jejich působením zmizí. (Latour 2005: 100)

Latour dává jako častý př́iklad právě náboženství, které mizí vždycky poté, co je „sociologicky vysvětleno“. V tomto př́padě máme naopak situaci, kdy vsunutí pojmu náboženství do jinak korektní, empiricky uzemněné analýzy přesouvá pozornost k otázkám, jež jsou ve vztahu k řešeným problémům zcela marginální. $\mathrm{V}$ tomto ohledu si lze z Latoura vzít jedno obecnější poučení: „Neviditelný činitel, který nezakládá žádný rozdíl, nezpůsobuje žádnou změnu, nezanechává žádnou stopu a nevstupuje do žádného popisu, není žádný činitel“ (Latour 2005: 53). ${ }^{5}$

\section{Nerealistické předpoklady: Svobodná moderní individua vs. nediferencovaná tradiční masa}

Problematičnost uvažování, které se tak snadno nechá svést líbivým a jen zdánlivě cosi vysvětlujícím slovem „náboženstvi“', je více než v uvedeném př́padě patrná při objasňování událostí, jež se odehrály na Filipínách a jež by měly dokládat vliv „náboženství“ na „politiku“. Vliv, který se Grace Davieové (2009: 147) jeví s ohledem na formální odluku státu a církve překvapivý. První z těchto událostí se stala roku 1986, kdy byla svržena diktatura prezidenta Marcose. Opozici proti prezidentovi totiž pomohla skutečnost, že kardinál vyzval katolické věrící, aby se přidali k „našim prátelům“ a ukončili „,vládu zla“. Svržení Marcose bylo následně prohlášeno za „mariánskou událost“, $\mathrm{k}$ nelibosti protikatolicky laděných evangelikálních skupin (Davieová 2009: 147-148). Davieová si proto myslí, že významným činitelem svržení Marcose byla „přitažlivost katolické církve“. Co touto „přitažlivostí církve“ konkrétně mělo být a proč by to nemohla být popularita zcela konkrétního kardinála z konkrétních vystopovatelných důvodů nebo třeba jen podepření názoru, že svržení Marcose není „proti vůli Boha“, uznávanou autoritou ve věcech morálky i „Boží vưle“, Davieová nijak neobjasňuje. Jako by věci již dostatečně objasnilo samotné použití metafory „přitažlivosti církve“.

Druhou událostí byly snahy odstranit z prezidentské pozice Josepha Estradu v roce 2001. Na rozdíl od předchozího př́padu však mnozí evangelikálové i řada katolíků spatřovali v Estradovi ochránce chudých, a protesty proto nepodpořili, dokonce se postavili za Estradu, takže reakce ani $\mathrm{v}$ táboře katolíků ani v táboře evangelikálů nebyla jednotná. „Přitažlivost církve“ se někam vytratila. Tato událost samotná není ničím př̌kvapivá, překvapivý je však komentář G. Davieové:

„An invisible agency that makes no difference, produces no transformation, leaves no trace, and enters no account is not an agency“. 
[N]a konci století už bude pravděpodobně správnější zkoumat politické hranice běžící např́íc jednotlivými denominacemi spíše než ty, které je od sebe oddělují. Jinak řečeno, politickou loajalitu už nelze jednoduše vyvodit $\mathrm{z}$ konfesijní př́islušnosti. Souvislosti mezi náboženstvím a politikou jsou podstatně složitější [...] a bude třeba podrobit je dlouhodobému podrobnému zkoumání. (Davieová 2009: 148)

Na tomto komentáři zaráží celá řada věcí: jednak zjevný předpoklad, že do konce 20. století byli lidé „stádem“ zcela podřizeným svému církevnímu „pastýři“, takže politickou loajalitu bylo možné ,jednoduše vyvodit z konfesijní př́slušnosti“. Jeho narušení je na tomto místě příčinou překvapení, jež vede k pochybám ohledně politické jednotnosti zprostředkované církevní př́slušností. Tento předpoklad je důležitý, protože je ve své podstatě součástí projekce minulosti v narativech sekularizace. Ty totiž pracují s představou, že zatímco v tradiční společnosti byli lidé vystaveni nediferencovanému působení církve, kterému se nedokázali vzepř́ít nebo ze kterého se nedokázali vymanit, tak v moderní době se tento svorník klenby společnosti rozpadl, čímž vznikli svobodní jedinci shromáždění v liberální společnosti. Tento předpoklad lze sice dohledat i u zakladatelů sociologické tradice, jako je Durkheim (2004: 246-248, 251-253), avšak právě na toto dědictví lze jen těžko navazovat.

Studium tzv. lidového křest’anství ve středověku dokládá naprostý opak toho, co někteří sociologové považují za samozrejmé:

Stačilo, aby se věřící nevyhýbali bohoslužbám, znali základní liturgické a svátostné úkony, aby platili církevní poplatky a pravidelně chodili k církevní zpovědi - a autority byly spokojeny. Jinak stačilo ovládnutí modlitby Otče náš a Věrím v boha [...], ostatní věroučné znalosti se ani nepředpokládaly, protože jejich zdůvodňování by se stejně minulo účinkem,

píše český medievalista Pavel Spunar (1999: 90-102, 94). Richard Dülmen (2002: 40) zase zdůrazňuje, že

[p] řestože křest’anské církve předepisovaly všem bez rozdílu jednotnou ortodoxní víru, vytvořili si obyčejní věřící vlastní náboženské představy, které, aniž by to jejich nositelé sami pocitovali, odporovaly oficiálnímu učení.

Tato záležitost ale měla i druhou stránku - přímou moc „lidu“ nad formováním učení církve. Rozhodnutí nikájského koncilu ohledně uctívání obrazů komentuje Pavel Spunar (1999: 98) následovně:

Církev vyšla vstříc prrání a potřebám věrících [kteří se modlili přímo k obrazům, nikoliv $\mathrm{k}$ těm, koho reprezentovaly]. Obrazy a sochy nemohla zakázat - vznikaly by stejně - a tak navrhla formuli „Kdo uctívá obraz, ctí tím zobrazeného“.

Ale výše uvedená představa je pochybná i z jiných důvodů. Předpoklad př́mého vlivu médií na jejich konzumenty těžce selhal v rámci mediálních studií, která dnes hledají nové možnosti konceptualizace oběhu a vlivu mediálních sdělení (viz např́iklad Tomaselli a Shepperson 2002: 349-354). Jinými slovy, masová produkce informace namířená na masu diváků a využívající bohatého repertoáru sociologického a psychologického know-how nedokáže to, co by, jak se domnívají sociologové náboženství jako Grace Davieová, měly dokázat církevní hierarchie ve společnostech, které neznaly tištěná či elektronická média a obývaly 
prostor, který byl mnohem méně propojený, mnohem více lokálně fragmentovaný. Co to bylo za zázračný svorník, který homogenizoval středověkou křest’anskou společnost, nebo co by mohlo být tou zázračnou mocí, která ještě nedávno politicky homogenizovala populace Filipín podle církevního/denominačního klíče? To by asi zajímalo nejen vědce, ale i současné PR manažery, reklamní producenty a totalitní vládce. ${ }^{6}$

Sociologové náboženství tedy mají někdy tendenci s pojmem náboženství spojovat tak odlišné věci jako církevní příslušnost a něco, co bychom mohli nazvat přesvědčení či postoje, což jsou ovšem věci, které spolu vůbec nemusí souviset. A to samozrejmě ještě neřešíme otázku, co je to „náboženská příslušnost“. Co znamená např́iklad kladná odpověd’

6 Jan Horský se ve své nedávné teoereticko-metodologické reflexi dějepisectví věnuje otázce, jakým způsobem může přispět historiografie ke korekci sociologické teorie a jako ilustrativní prríklad volí právě teorie sekularizace a ukazuje, že na základě i jen pouhé „sekundární empiričnosti“ lze snadno zpochybnit právě předpoklady durkheimovské sociologie (a historiografie v podobě studia mentalit ve škole Annales) o jednotě sdílených kolektivních reprezentací zajišt'ujících sociální soudržnost tradiční společnosti. Odkazuje přitom na několik prací k historii českých zemí, které podrobněji dokládají heterogenitu „vědomi“" středověkých a raně novověkých společností, a to jak pokud jde o konfesijní př́slušnost (kde heterogenita zasahovala i do rodin), tak pokud jde o „mentality“ i „rituálové systémy“ (Horský 2009: 152-157).

David Zbíral (2011) ve své studii zaměřené na osobní religiozitu Armanna Pungilupa z Ferrary žijícího ve 13. století, aktivního laika, který díky svému „zbožnému“ životu po smrti úspěšně nastoupil cestu uctívaného světce, aby se po zásahu dominikánů a z něho vzešlých následných sporů nakonec stal kacířem, ukazuje nejen jeho v mnoha ohledech neortodoxní postoje, ale především jeho schopnost kritického praktického nadhledu, s nímž si dokázal z řady ortodoxních představ, rituálních postupů a církevních představitelů tropit žerty a zesměšňovat je, aniž by z toho vyplývalo, že je v jiných kontextech nectí, a svým jednáním tak unikat mnohým snahám (sousedů i inkvizitorů) zaškatulkovat jej do té či oné sekty, mezi zbožné či pochybovače, a nakonec tedy také mezi laické světce či kacíŕe. Jedním z výrazných závěrů textu je vlastně to, že jeho religiozita byla tak mnohoznačná a kontextuálně proměnlivá, že se nám rozpadá nejen obraz člověka podřizeného zcela církevnímu učení, ale i nábožensky homogenní osobnost. Pungilupo nás vlastně mimo jiné učí, že samotný život jedince je tak bohatý zvláštními kontexty a různorodými situacemi, jimž musí čelit, že jej vlastně nelze svázat ani ucelenou doktrínou, ani ucelenou praxí, natožpak ucelenou doktrínou, by systematicky převáděl do svého každodenního jednání. Něco takového chtěl také David Zbíral naznačit, když v jedné z pracovních verzí textu svůj závěr vypointoval tvrzením: „Když se na závěr tohoto pokusu o rekonstrukci osobní religiozity Armanna z Ferrary ohlížím zpět, vnucuje se mi otázka, zda jsem celou tuto cestu nepodnikl jen proto, abych zjistil, že byl Armanno člověk.“

$\mathrm{Z}$ antropologické perspektivy se do tohoto nelidského předpokladu pustila Mary Douglasová, která jej v práci jinak obhajující právě durkheimovskou sociologii kritizovala vyloženě v souvislosti s představami o sekularizaci moderních společností: „Protiklad sekulárního vůči náboženskému nemá nic společného s protikladem moderního vůči tradičnímu nebo primitivnímu. Představa, že primitivní člověk je ve své přirozenosti hluboce náboženský, je nesmysl. Pravdou je, že v kmenových společnostech lze narazit na všechny varianty skepticismu, materialismu a duchovního zápalu. Tyto společnosti se od sebe v tomto ohledu navzájem odlišují stejně jako rozličné segmenty londýnského života. Iluze, že všichni primitivové jsou zbožní, dưvěřivi a oddaní učením kněži a kouzelniků, uškodila našemu úsili porozumět vlastní civilizaci možná více než snahám archeologů vyložit mrtvou minulost" (Douglas 2010: 18; proložení není součástí původního textu, ale mým zdůrazněním důsledků). 
na dotazníkovou otázku po církevní př́ślušnosti? Že je daná osoba - jedná-li se o některou z křest’anských církví - pokřtěna? Nebo že chodí v neděli do kostela? Nebo že žije na vesnici, kde si všichni zakládají na tom, že jsou „katolíci“ (protože ve vedlejší vesnici jsou všichni „evangelíci“)? Richard Dülmen v tomto ohledu opět upozorňuje, že nejen v chladně náboženských středověkých evropských společnostech, ale ani v po-restauračním období v 19. století, které přineslo jevy jako pravidelné návštěvy kostela,

[p]ríijímání církevních nabídek duchovní péče jen zřídkakdy probíhalo ve smyslu oficiální „teologie“; do kostela se chodilo i z „nenáboženských“ důvodů. Jen ze skutečnosti, že všichni lidé byli křtěni a křesł’ansky pohřbíváni, že se v nouzi modlili a že chodili do kostela, nelze vyvozovat, jak „křest’ansky“ se daná společnost chovala. (Dülmen 2002: 62-63)

Jak za těchto okolností rozumět další souvislosti, kterou Davieová naznačuje, totiž mezi církevní příslušností (v neznámém smyslu a vyjádřené zmatečně výrazem „náboženství") a politickým jednáním? Řekl bych, že především tak, že tu jde opět o Latourem zmiňované nahrazení jedné entity druhou, místo o vzájemné propojení různých jevů prŕččnnými vztahy. Klíčové slovo, které ve zdůvodnění Estradova odstranění padlo, totiž znělo „chudoba“. Vlastně nešlo o nic jiného než o prezentaci smysluplného předpokladu, že jistá mocenská konstelace je pro nízkopř́ijmové skupiny výhodnější než jiná. To je celkem srozumitelné. Pokud bychom ale Davieové komentár dovedli do důsledků, mohlo by to znamenat, že zájem o vlastní žaludek nebo peněženku je fenoménem, který se objevuje až koncem 20 . století a $\mathrm{k}$ jeho objasnění sociologii pomůže podrobnější a dlouhodobé studium vztahů mezi politikou a náboženstvím. ${ }^{7}$ Mně osobně přijde smysluplnější, když budeme brát vážně společensky marginalizované lidi ve chvíli, kdy oceňují skutečnost, že je jiní lidé přijímají mezi sebe jako rovnocenné lidské bytosti, nebo lidi žijící v ekonomické nejistotě, když vyjadřují obavy $\mathrm{z}$ toho, že odstranění nějakého politika $\mathrm{v}$ jejich př́ípadě povede $\mathrm{k}$ ještě větší bídě. Pokud při tom zároveň zmíní nějakou církev, konkrétního církevního představitele nebo třeba Ježíše Krista, lze se smysluplně ptát, jakou práci takoví aktéři odvádí. Ale není nejmenší důvod nahrazovat zcela bezdůvodně problémy s alkoholem, spásné působení Krista či obavy o vlastní žaludek, ,jednoduchým, homogenním, banálním a víceúčelovým“ (řečeno s Latourem), beztvarým a matoucím termínem „náboženství“.

\section{Oddělení náboženského a nenáboženského a řád moderní společnosti}

Výše uvedené problémy částečně vyplývají z povahy sociologické práce s kvantitativními daty. Jednak jsou data $\mathrm{v}$ datových souborech již svou formou tak vzdálena konkrétnímu lidskému jednání, že se snadno zapomene na to, k čemu sesbíraná čísla konkrétně odkazují, jednak už u datového vstupu obvykle nemáme tušení, co vlastně znamená. Částečně však

7 S takto vyhroceným tvrzením by pochopitelně Grace Davieová, a asi ani nikdo jiný, nesouhlasili. Co se tímto dovedením věcí ad absurdum snažím naznačit, je, k jak velkým nesmyslům uvedené ledabylé zacházení s „,náboženstvím“ vede. To, že vyhrocené tvrzení absurdnost rozebíraného typu úvah ukazuje takto názorně, neznamená, že tvrzení, z nichž tato absurdnost není patrná ve stejné míře, jsou méně absurdní. 
uvedené problémy souvisí, jak již jsem naznačil, s některými teoretickými předpoklady zabudovanými v tradici sociologického myšlení a s rutinními metodickými postupy, jako je spoléhání se na beztvarý pojem náboženství, kombinovanými s vírou, že takový pojem označuje něco jasného, a tak umožňuje vysvětlit jiné věci. Je namístě se proto podívat na to, jak se tento koncept $\mathrm{v}$ sociologické tradici etabloval. Mezi sociology náboženství mají z „otců zakladatelư“ prominentní místo dva: Max Weber a Émile Durkheim.

Role Weberova dědictví ve výše uvedených problémech je rozporuplná. Weber zásadním způsobem formoval diskusi o sekularizaci svými úvahami o progresivní racionalizaci moderní společnosti a odkouzlování světa. Na druhou stranu, jeho diskuse na tato témata vycházely z jeho zájmu o porozumění povaze kapitalismu. Osud náboženství ve smyslu proměny role, funkce či významu nějaké specifické oblasti společenského života jej vlastně, na rozdíl od pozdějších sociologů náboženství, nezajímal. Výše uvedené procesy také nepojímal jako procesy, jež by cosi činily s náboženstvím. Nahlížel je spíše jako procesy vedoucí k utváření nových společenských struktur, ale uvedené do pohybu proměnami hodnot a strategií jednání $\mathrm{v}$ určitých - pro další směřování společnosti jako celku významných - segmentech společnosti. Jinými slovy diskuse o sekularizaci je Weberovi v mnohém zavázána, ale zároveň je vlastně zploštěním komplexních problémů, které se pokoušel řešit. ${ }^{8}$ A zatímco Weber vůbec nepotřeboval vymezit, co náboženství je, a jasně je analyticky oddělit od oblasti ne-náboženského, protože o něčem jako oddělení subsystémů společnosti neuvažoval, sociologové sekularizace museli toto rozlišení rozpracovat. Není proto náhoda, že řada z nich, jakkoliv celou diskusi rámovali Weberovými kategoriemi, se musela při snaze vyřešit otázku oddělení náboženského a nenáboženského poohlédnout po jiném vzoru.

Např́klad Peter Berger (1990: 113-120) ve své klasické práci navázal na Weberovy úvahy o „náboženských“ zdrojích sekularizace tím, že tendence k ní nacházel již v transcendentalizaci boha, historizaci a racionalizaci etiky patrných ve starozákonních vyprávěních. Ovšem k tomu, aby - obzvláště v teoretickém rámci vymezeném Sociální konstrukcí reality mohl otevř́it téma náboženství v moderní společnosti jako problém sekularizace, potřeboval náboženství vymezit pomocí nějaké substance, která umožní odlišit „náboženské“ prostředky legitimizace sociálního řádu od těch „nenáboženských“. Využil k tomu - s explicitním odkazem na Rudolfa Otta a Mirceu Eliadeho - koncept posvátna (Berger 1990: 25-26). K tomu, v čem spočívá problematičnost tohoto kroku, se ještě vrátím. V tuto chvíli je podstatné, že Weber sociologické tradici nezanechal potřebná vodítka pro zacházení s kategorií náboženství, jakkoliv jí odkázal řadu zásadních otázek, často i s duchaplnějšími odpověd’mi, než s jakými přichází současné bádání.

Druhý z uvedených klasiků, Émile Durkheim, byl v tomto ohledu v Elementárních formách náboženského života (2002 [1912]) ke svým následovníkům vstřícnější. Přesto je i jeho dědictví tak trochu danajským darem, s nímž si př́liš nevědí rady. Např́klad Karel Dobbelaere se ve své vlivné monografii o sekularizaci pustil do analogické operace jako

8 Roman Vido na obecnější rovině poznamenává, že „[n]emá př́liš smyslu hovořit o ,sekularizačních teoriích“ v souvislosti s klasickými sociologickými teoriemi s odvoláním na fakt, že už v nich můžeme nalézt důležité úvahy o osudu náboženství v moderních společnostech (Comte, Marx, Durkheim, Weber)“(Vido 2011: 22). 
výše uvedený Berger, přestože vycházel z Durkheimovy definice náboženství. Je př́íznačné, že Dobbelaere (2002: 50) se v kontextu diskuse o sekularizaci zalekl důsledků funkcionální definice náboženství, která tuto diskusi vlastně znemožňuje tím, že zahrnuje vše, co má ve společnosti onu „náboženskou“ funkci, at’ už je jí míněno cokoliv. Dobbelaere zde také upozornil na to, že „odborníci pracující s funkcionální definicí stejně do svých definic zavádí implicitně nebo explicitně substantivní prvky, aby se vyhnuli argumentaci kruhem“ (tamtéž). At’ už je funkce náboženství vymezena jakkoliv, zdá se být obvykle pro fungování společnosti tak nevyhnutelnou, že je prakticky nemožné, aby nebyla nějakým konkrétním způsobem naplňována. Sociologii náboženství pak vlastně nezbývá než ji jasně definovat a pak popisovat, jak je v té či oné společnosti naplňována. Problém samozřejmě tkví v tom, jak takovou společenskou funkci přesně popsat empiricky a jak doložit, že to či ono ve společnosti právě takovou funkcí plní a že to plní funkci právě jen tu a ne jinou. Je zřejmé, že jakákoliv společnost je, pokud jde o zájmy různých skupin aktérů, značně heterogenní, takže kterákoliv instituce může mít ve vztahu k různým kolektivům funkce značně odlišné, ba protikladné. $Z$ hlediska společnosti jako celku ve smyslu nějakého jednotného systému jsme pak schopni identifikovat konkrétní funkci jen za předpokladu, že víme, jaký je účel celku a kam onen celek směřuje. To pochopitelně nevíme, což je pro funkcionální sociálněvědné uvažování těžko řešitelný problém. Nejen Dobbelaere se proto vydává jinou cestou.

\section{Nadprirozené a nadempirické}

Dobbelaere Durkheimovu definici náboženství prakticky doslova přejímá, ale jako substanciální prvek dodává to, že daný systém věr a praktik odkazuje na „nadempirickou“, „transcendentni“" skutečnost (tamtéž: 52). Protože jsou ale pojmy jako „transcendentni““ a „,nadempirický“" spojeny s velice parciální metafyzickou koncepcí, tj. s určitým uspořádáním reality platným pro specifickou komunitu, vnáší do vztahu sociologie a společnosti, kterou zkoumá, mocenskou asymetrii a s ní zcela konkrétní normativitu. Tato normativita poskytuje zvláštní perspektivu založenou na určité představě o tom, jaké skutečnosti lze legitimně empiricky zakoušet a jaké zkušenosti sice lidé mohou zakoušet také (čili jsou součástí nějaké empirie a jejího popisu), ale již ne jako zkušenosti empirické v pravém smyslu slova, ale pouze jako něco, co je projevem nějaké ,jiné“ (v podtextu zní: méně reálné) reality. V takové perspektivě lze tedy etnocentricky studovat jinou než vlastní společnost, avšak nikoliv společnost vlastní, jejíž uspořádání se o tutéž normativní představu opírá. Studium té vlastní společnosti by bylo možné jen tehdy, kdyby tato představa nevstupovala do reflexe jako výchozí předpoklad zakládající ústřední definiční pojmy, ale naopak by byla zpochybněna a sama o sobě tematizována jako problém. Kdyby byla položena otázka, kde se vzala tato normativita jako něco, čemu odpovídá řád této konkrétní (tj. naší) společnosti.

Prvořadým cílem sociologie ale nikdy nebylo studovat jinou společnost, tj. společnost „tradiční“. „Tradiční“ společnost má sociologii jen poskytovat určitý heuristický model umožňující studovat společnost vlastní, tj. „,moderní“. Jenže to není možné. K tomu by bylo potřeba, aby právě hledisko „tradiční společnosti“ - pokud už tedy byla zvolena strategie heuristického porovnávání modelu jedné společnosti se společností druhou - bylo použito jako rámec pro studium společnosti „moderní“. Vše by tedy muselo být přesně naopak. Jen 
pak by bylo možné nevycházet z konkrétního uspořádání jako ze samozřejmosti, ale mohlo by být studováno jako zvláštní předmět. Jen takovým opatrným heuristickým postavením se na stranu jiného by bylo možné dosáhnout symetrického př́stupu v tom smyslu, že by, jak ř́ká John Law, byla eliminována veškerá privilegia, rozdíly, o nichž se věří, že vyplývají z přirozenosti věcí, a bylo by tedy možné se tázat ,jak se stalo, že se věci uspořádaly právě tím konkrétním způsobem?“(Law 1994: 12).

Je při tom zajímavé, že tento druh problémů si uvědomoval už Durkheim samotný, když v obsáhlé úvaze o pojmu náboženství odmítl možnost vymezit jej prostřednictvím pojmu nadpřirozeného. Tento problém je totiž s problémem jeho vymezení prostřednictvím pojmů „nadempirický“ a „transcendentní“ identický. Objasnění podané Durkheimem je velice prosté: nadpřirozené dává smysl pouze jako párová kategorie k pojmu přirozeného, který je zase vázán na osvícenskou představu přirozeného/přírodního zákona a na moderní vědu. $Z$ toho důvodu je absurdní připisovat víru v „nadpřirozeno“ „primitivnímu“ člověku (Durkheim 2002: $33 \mathrm{nn})$.

Trochu obšírněji totéž formuloval výrazně později postkoloniální teoretik, antropolog Talal Asad (2003: 27-28). Asadův př́spěvek je v tomto ohledu důležitý proto, že ukazuje, jakým způsobem je pro moderní diskursy o náboženství konstitutivní vzájemné propojení dvou binárních opozic nadpririrozeného a přirozeného a posvátného a profánního. To nám jednak dovolí trochu lépe si ujasnit, proč je stejný problém i s výše zmíněným pojmem nadempirického, jednak to $\mathrm{z}$ jiného úhlu pohledu vrhne světlo na to, $\mathrm{v}$ jakém smyslu výše hovořím o konkrétním uspořádání skutečnosti, a proč tedy do diskuse zapojuji Johna Lawa. Ten v návaznosti na citované tvrzení dále objasňuje, že „princip symetrie je jednoduše metodologickou reformulací vztahu mezi uspořádáním a uspořádáváním“ (Law 1994: 12), a upřesňuje, že bychom konkrétní uspořádání neměli samozřejmě přijímat, ale naopak s nimi nakládat jako s výsledky uspořádávajících aktivit.

Podle Asada je jedním z aspektů tohoto problému fakt, že náboženské je v rámci opozice přrirozeného a nad-přirozeného jednoznačně identifikováno s nad-přirozeným. Mimo jiné se v důsledku toho objevuje i představa „náboženské zkušenosti“ jako specifické oblasti vnímání. Jinými slovy, posvátné je $\mathrm{v}$ tomto diskursu svázáno s nadpřirozeným, zatímco profánní s přirozeným. Asad nicméně upozorňuje, že tato dichotomie posvátného a profánního, korespondující s dichotomií přirozeného a nadprirrozeného, neexistuje např́klad ve středověkých evropských textech, které sice znají opozita jako „božský“ a „satanský“ či „spirituální“ a „temporální“, ale nikoliv „posvátný“ a „profánni““. Nejen nadpřirozené, ale i posvátné je tedy specificky moderní západní konstrukcí.

Tato konstrukce však nezahrnuje pouze dvě uvedené kategorie. Jedná se o komplexnější kategoriální uspořádání, v němž vzájemně vztažené kategorie nadpřirozeného a posvátného doplňují jejich binární opozice „přirozené“ a „profánní“. Náboženství je v tomto uspořádání jednoznačně na straně vymezené nadpřirozeným a posvátným. Společenské oblasti jako věda a politika pak stojí na straně opačné - profánní a přirozené (Asad 2003: 31-33). A právě v tom smyslu je samotný pojem náboženství jako určitý „intelektuální“ nástroj také součástí specifického společenského uspořádání, které zahrnuje takové věci, jako jsou specifická organizace správy věcí veřejných a produkce pravdivého odborného vědění. $Z$ tohoto společenského uspořádání také vychází onen normativ, o němž jsem mluvil v souvislosti s Karlem 
Dobbelaerem. A právě proto si sociologové, kteří vychází z pojmů jako „nadempirický“, „nadprirozený“, „posvátný“, „,náboženství“ jako z daností, místo toho, aby se ptali, slovy Johna Lawa, ,jak se stalo, že se věci uspořádaly právě tímto konkrétním způsobem?“،, znemožňují poznávat přesně to, co chtějí poznávat na prvním místě, tu společnost, v níž praktikují své povolání.

Za této situace může studium náboženství kolektivům, jimž dané uspořádání vyhovuje, sloužit jako podpěra a efektivní legitimizační nástroj, avšak nelze s jeho pomocí toto uspořádání samotné sociologicky relevantním způsobem tematizovat. Přesně na to koneckonců upozorňuje další postkoloniální teoretik a kritik zacházení s pojmem náboženství v západní vědecké tradici Timothy Fitzgerald. V článku „Playing Language Games and Performing Rituals: Religious Studies as Ideological State Apparatus“ podrobně dokládá, že

„náboženství“ je jen jednou částí párové kategorie, jejíž druhou částí je „nenáboženské“ čili „sekulární“. Formulaci moderního pojmu náboženství je třeba sledovat v souvislosti s privatizovanou protestantskou zbožností (pietou) a oddělením státu a církve. Díky tomu se mohla ustavit demystifikovaná lidská přirozenost a plně racionální moderní občanská společnost. Uplatněním distinkce náboženské-sekulární na zvyšující se množství kolonií se „náboženství“ následně stalo všezahrnujícím úložištěm pro veškeré domorodé instituce a praktiky bránící pokroku (tj. bránící domorodcům v osvojení si sekulární racionality). (Fitzgerald 2003: 209)

A v tomto procesu, objasňuje dále Fitzgerald, sehrávají badatelé o náboženství zásadní roli jako ti, kdo svými vědeckými aktivitami vykonávají rituály, jejichž výsledkem je zakrývání zmíněné vazby mezi náboženským a nenáboženským a s ním celého sociálního uspořádání, o němž jsem hovořil výše a které popsal Fitzgerald v předchozí citaci: prostřednictvím výzkumné činnosti se produkuje náboženství jako samostatná, nezávislá kategorie (Fitzgerald 2003: 210). Trik spočívá $\mathrm{v}$ tom, že tato kategorie nemá jiný jasný obsah než právě vztahové vymezení vůči ne-náboženskému: „Problém pak vzniká z toho důvodu, že hranice mezi náboženským a ne-náboženským se neustále přesouvá v závislosti na kontextu“ (tamtéž). ${ }^{9}$ Jak?

To ilustruje Fitzgerald na př́kladu zpravodajství BBC informujícího o tragické smrti patnácti studentek internátní školy v Saúdské Arábii. Dívky uhořely mimo jiné proto, že okna jejich pokojů byla zajištěna proti otevření a dveře zavřeny na petlici s cílem omezit dívkám možnost pohybu, aby se mohly soustředit na učení a aby v nich byla rozvíjena cudnost a poslušnost. Záchranáŕi naopak věděli, že dívky nemohou zachraňovat, pokud nejsou dostatečně oblečené. $V$ důsledku toho zemřelo patnáct dívek oblečených v nočním úboru. Celá záležitost byla pak rámována jako problém náboženství a nepř́ípadného uplatnění zbožnosti (piety). Důvodem takového pochopení problému byla pouze skutečnost, že normy, jimiž se všichni zúčastnění ř́́dili a jimž odpovídalo i ubytování dívek, vycházely ze saúdskoarabského práva, šaríi. Saúdská Arábie totiž mezi „sekulárním“ a „náboženským“ právem nerozlišuje. Má jen jediné - šaríu. Pokud ovšem znamená jednání v souladu s právem zbožnost, ptá se Fitzgerald, proč takové jednání nenazýváme zbožností v našich vlastních společnostech? Ve všech př́padech to má přece stejné důsledky:

$9 \quad$ Fitzgerald zde odkazuje na práci Davida Chidestera Savage Systems: Colonialism and Comparative Religion in Southern Africa (1996). 
Jsou vhodné a nevhodné způsoby, jak vykonávat [různé] aktivity a selhání při jejich správném vykonávání může mít za následek výsměch, nesouhlas, přehlížení nebo jiný prostředek, jímž se člověku dává pocítit pravověrnost. (Fitzgerald 2003: 249)

Ani v př́padě Saúdské Arábie, ani v jakémkoliv jiném případě konformity s právem či morálními normami totiž nemáme nejmenší důvod předpokládat - v souladu $\mathrm{s}$ tím, jak by argumentovali někteří badatelé o náboženství -, že je zde konformní jednání doprovázeno nějakým vnitřním uvědomováním si Alláha jako nějakého „,nadpřirozeného“ či „nadempirického" aktéra.

Tím se dostáváme k druhému aspektu věci. Právě koncepty jako „empirický“ či „nadpřirozený“, které nelze zakotvit jinak než metafyzicky, umožňují velice jednoduše neustále posouvat hranici mezi náboženským a ne-náboženským, o níž Fitzgerald hovořil, prostě podle toho, jak se to momentálně hodí. To proto, že jejich uplatňování nebývá kontrolováno prostřednictvím jednoznačné definice, ale vychází z konkrétního úzu v konkrétním společenství, které principiálně považuje za přirozené a empiricky založené to, čemu věří samo, a za nadpřirozené a nadempirické to, co se od toho liší a čemu věří jiní. Jinými slovy, z uspořádání, které je výsledkem konkrétních interakcí konkrétních lidí a společenství v konkrétní době, vytváří objektivní univerzální měřítko, jehož objektivita je pochopitelně ještě zdůrazněna tím, že ,přirozenost“ a „empiričnost““ jsou v této společnosti výsadou pravého vědění, tedy vědy.

Toto jsme si uvykli nazývat etnocentrismem či predsudky a obviněním z tohoto nešvaru dnes celá řada debat končí, protože jsme si zvykli na to, že etnocentrismus je špatný. Ti, kdo mají pocit, že se věda prostě předsudků nemůže zbavit, díky tomu mohou oprášit princip objektivity klasického pozitivismu a prohlásit, že jinak to nejde, a postmoderní blouznění je proto třeba opustit (viz Martin a Wiebe 2012). Problém ale nespočívá v samotném faktu, že něco použijeme jako měřítko. Problém je v tom, že je toto měřítko použité jako měřítko objektivní a absolutní. Právě proto je mocensky efektivní a zároveň teoreticky problematické. Když nějaké věci porovnáváme, vždycky je navzájem nějak poměřujeme. Není ovšem jediný důvod, proč by dvě měřítka prostě nemohla být vzájemně relativní. Pokud pak jejich vzájemnou relativnost důsledně v analýze zohledníme, a učiníme tedy své poměřování symetrickým, vzájemně ekvivalentním ${ }^{10}$, budou naše analýzy pronikavější, méně etnocentrické. Takový postup, jak říká Karin Knorr Cetina (1999: 4), totiž činí neviděné věci viditelnými tím, že vzorec v uspořádání jedné z nich využívá jako optiku pro identifikaci a mapování vzorců v té druhé a naopak.

„A naopak“ je tu potřeba zdůraznit. V „a naopak“ spočívá rozdíl mezi symetrickým př́istupem na jedné a stereotypním sebevymezením se vůči druhému na druhé straně. „A naopak“ tu totiž reprezentuje tu vzájemnou relativnost, která umožňuje, že prostřednictvím jednoho vzorce odhalujeme teoreticky nosné nesamozřejmosti na druhé straně,

10 Mnohem podrobněji rozebírá tento problém Bruno Latour v kapitole „Absolute Relativism and Relativist Relativism“ (Latour 1993: 111-114). Pro badatele o náboženství pak může být relevantní také četba navazující kapitoly „Small Mistakes Concerning the Disenchantment of the World“. K objasnění kontextu může být potřebné přečíst celou část 4 „Relativism“ (91-129) a část 2 „Constitution“ (13-48), príípadně část 3 „Revolution“ (49-90). 
a prostřednictvím druhého totéž na straně první. Podstatné je to, že takto získané nesamozřejmosti jsou zviditelněné věci, na jejichž původ, detailní uspořádání atd. se díky zviditelnění můžeme nově tázat; můžeme zjišt’ovat něco nového díky tomu, že máme podnět pro kladení nových otázek. Nejde tedy o identifikaci nějakých esenciálních rozdílů, jak zdůraznila Knorr Cetina, ale o podněty pro postupující analýzu.

Pokud význam této symetričnosti podceníme, vznikají pochopitelně těžko řešitelné problémy. Některé z těch, jež jsou zároveň spojeny s uplatňováním konceptů nadpřirozeného a nadempirického, lze ilustrovat na prríkladu formování okultního hnutí v poslední třetině 19. a první polovině 20 . století. Okultisté, ${ }^{11}$ kteří se zabývali fenomény, jež ještě stále přijdou velmi obskurní jak některým teologům (viz například Stamm 2002), tak některým badatelům o náboženství, ${ }^{12}$ jakkoliv naprosto vážně jsou brány v kolektivech, jejichž představy a praktiky jsme si uvykli nazývat „New Age“ (viz Hanegraaff 1998), ${ }^{13}$ se především vší silou snažili přesvědčit ostatní, že jde o fenomény naprosto „přirozené“, dokonce empiricky zkoumatelné vědeckými metodami (viz Fujda 2008b: 62-70, 2010a: 135-149). Proto také Hanegraaff o okultismu hovoří jako o výsledku sekularizace renesanční esoterické tradice a na významných okultistických konceptech, jako je „životní magnetismus“, ukazuje propustnost hranice mezi „,ědou“ a „náboženstvím“, a tedy také empirickým a nadempirickým. Vědec Franz Anton Mesmer přichází s představou gravitační síly, kterou vesmírná tělesa, jako Měsíc, ovlivňují nejen př́iliv a odliv, ale také těla lidí. Toto pojetí rozvine do konceptu životního magnetismu, který je v roce $1775 \mathrm{v}$ jedné vědecké kontroverzi využit mnichovskou Akademií věd ve formulaci autoritativního stanoviska ohledně léčebných úspěchů exorcisty Johanna Gaßnera. Ty podle ní nejsou ani výsledkem „,podvodu“ ani „,nadpřirozených zázrakư“, ale prostého působení „přírody“. Vysvětlení spočívá v tom, že Gaßner disponuje „přebytkem životního magnetismu, který mu umožňuje obnovovat $\mathrm{v}$ jeho pacientech stav magnetické rovnováhy a tím je léčit“" (Hanegraaff 1998: 432).

Akceptuje-li sociolog náboženství pojem „nadpřirozeného“ jako podstatný aspekt náboženství, stává se při vymezení svého pole bádání závislým na dočasných výsledcích uvedených rozepř́i stejným způsobem jako Grace Davieová na tvůrcích dotazníků a státních a církevních byrokratických aparátech. Těžko si však představit, jak takovou závislost vědecké disciplíny na víceméně nahodilých výsledcích momentální konstelace sil ve společnosti věrohodně zdůvodnit. Stejně tak si nelze dobře představit, že by sociolog okultistovi, který mu vysvětluje, že duchové jsou „skořápky“ zemřelých, s nimiž lze normálně rozmlouvat, normálně je cítit, př́padně je vyfotografovat, a že se tedy jedná o naprosto přirozené a smysly vnímatelné věci, řekl: To je sice hezké, ale ty, hloupý okultisto, se samozřejmě mýlíš a já jakožto sociolog vím, že jde o věci nadpřirozené a nadempirické. Jednak není jasné, odkud by sociolog jakožto sociolog měl disponovat autoritativním poznáním ontologické povahy

11 K vymezení pojmu okultismus, jak mu zde rozumím, viz Fujda (2008b: 58-62, 2010a: 131-134).

12 Diskuse o obtížích s etablováním studia západního esoterismu jako legitimní oblasti bádání viz Hanegraaff (1998a).

13 Hanegraaff podrobně a důsledně objasňuje historické vazby mezi New Age, esoterismem a okultismem, respektive ukazuje, v jakém smyslu jsou všechny tři různými historickými etapami v historickém vývoji jedné alternativní duchovní tradice, jež se rodí v renesanci. 
skutečností, jako jsou duchové, jednak se zdá skoro triviálním konstatování, že taková tvrzení okultisty jsou pro něj základními empirickými danostmi (jakožto tvrzení okultisty), takže skutečnost, že pro něj takové věci nejsou ani nadempirické, ani nadpřirozené, musí přijmout prostě jako fakt (diskursu). ${ }^{14}$

Uvedené poznámky také objasňují, v čem spočívá význam studia fenoménů, jako jsou okultismus nebo New Age, pro současnou sociologii náboženství, respektive sociologii vůbec. Jsou to fenomény na okraji, ${ }^{15} \mathrm{v}$ nichž se zachází $\mathrm{s}$ př́iliš velkým množstvím toho, čemu Latour říká „hybridy“, což stručně řečeno znamená skutečnosti, které nemají jasné místo $\mathrm{v}$ etablovaném uspořádání věcí a jejichž existence je $\mathrm{v}$ jeho rámci tedy systematicky zakrývána, respektive nelze je $\mathrm{v}$ tomto uspořádání reprezentovat, činit viditelnými a myslitelnými (Latour 1993: 34). ${ }^{16}$ Proto také, domnívám se, naráží samotná tematizace těchto problémů na odpor, který rozebírá Hanegraaff (1998a). Latour (1993: 39-40) pak upozorňuje, že v důsledku toho, že nejsme schopni analyzovat, co s hybridy činíme a čím jsou pro etablovaný řád důležití, nejsme také schopni konceptualizovat sami sebe ve své kontinuitě s našimi „předmoderními“" předky. Ve chvíli, kdy tyto hybridy vezmeme vážně a učiníme svá měřítka vzájemně relativní, přestane být naše vědecká praxe závislá na tom, co je v tom či onom konkrétním okamžiku v nějaké momentálně významné části naší společnosti právě považováno za „nadpřirozenée“ a „nadempirické“. Budeme tak schopni místo konstruování nepřekonatelných rozdílů mezi námi a jinými důsledně studovat, jakým způsobem se utváří, etablují a rozpadají rády jak společenství, v nichž žijeme, tak těch, v nichž nežijeme, a to, v čem se tyto procesy uspořádávání a jejich výsledky konkrétně liší a proč. Také si ujasníme, proč se přesvědčení, že v moderní společnosti klesá míra víry v nadpřirozeno, zastávané např́ílad Stevem Brucem (2002: 58), prakticky rovná opět absurdnímu tvrzení, že moderní společnost se liší od společností tradičních tím, že její př́slušníci nevěří v tak velké míře $\mathrm{v}$ to, $\mathrm{v}$ co $\mathrm{v}$ tradičních společnostech nikdy z principu ani věřit nešlo.

14 V této souvislosti se cítím povinen odkázat na diskusi, která se ohledně sociologické povahy uchopení „náboženských“ skutečností vedla v časopise Biograf, 2010, č. 52-53 a 2011, č. 54. Především bych chtěl upozornit na text Jana Palečka (2011) „Kde všude jsou lvi?“. Jan Paleček zde reaguje na kritiku (Fujda 2010b; Krcha 2010; Tížik 2010) svého původního příspěvku (Paleček 2010), a je tak nucen velice podrobně objasnit celou řadu nedorozumění, k nimž došlo at' již v důsledku formulačních nepřesností nebo nepozorným čtením. Důkladně se tak věnuje i některým problémům, které tu otevírám nyní já. Bezprostředně relevantní a podnětné jsou především odstavce 5 až 11 . Hanegraaff (2002: 302-308) na jiném místě hovoří o New Age jako o „sekulárním náboženství“. Jan Paleček se Zdeňkem Konopáskem jako fenomény shodně se nacházející na rozhraní studovali zjevení a posedlosti a způsoby, jakými se s nimi zachází v pastorální a psychiatrické praxi. Bruno Latour zde má na mysli primárně objekty-subjekty, které nezapadají do klasifikace na př́irodu a kulturu, jejíž samozřejmé přijímání v jeho analýze představuje základní vymezení toho, co znamená být moderní. Ale domnívám se, že není nevhodné tento pojem v souladu s jeho užíáním v rámci tradice kulturálních studií a myšlení o identitě v jejím rámci (viz např́íklad Bhabha 2004) uplatnit na jakékoliv objekty-subjekty narušující etablované hranice, a tedy uspořádání. Latourovo vymezení modernity prostřednictvím přijímání „ústavy“, v níž je svět strukturován primárně podle distinkce př́roda/kultura a jí odpovídajícího způsobu organizace vědění a politiky, nicméně vrhá jiné světlo na problém „,nadpřirozeného“v sociologickém myšlení o náboženství. 
Dosud jsem se však věnoval jen tomu, v čem problémy současné sociologie náboženství vyplývají z toho, že si sociologové nevzali k srdci jedno důležité klasikovo poučení. Některé problémy však jednak zapříčinil sám Durkheim svým odkazem dalším generacím, jednak vyplývají z jisté simplifikace toho, co Durkheim sociologické tradici předal. Na tyto aspekty bych se rád podíval $\mathrm{v}$ následující části textu prostřednictvím rozboru důležitých aspektů Durkheimovy definice náboženství a způsobu, jakým Durkheim s konceptem náboženství ve své práci naložil.

\section{Durkheim a vymezení oblasti náboženského}

Mnohokrát opakovaná a všeobecně známá Durkheimova definice ř́iká, že

náboženství je jednotný systém virry a praktik vztahujicich se k posvátným věcem, to jest věcem odtažitým a zakázaným; systém viry a praktik, které sjednocují všechny své přivržence v jediném morálním společenstvi nazývaném církev. (Durkheim 2002: 55-56; kurzíva v originále)

Jednou z věcí, která je zásadní jak pro Durkheimovo myšlení o náboženství, tak pro nakládání s náboženstvím v navazující tradici sociologie náboženství, jsou pojmy „,posvátné věci“, tj. „,ěci odtažité a zakázané“, a pojmy „morální společenství“, respektive „církev““.

\section{Posvátné věci}

Pojem posvátného hraje v Elementárních formách zásadní roli. Durkheim (2002: 45), jak se zdá, považuje klasifikaci světa do dvou sfér - posvátné a profánní - za univerzální emickou představu. Nejde tu přitom jen o trrídění věcí, ale i času a prostoru. Problémy související s tímto v sociologii (na rozdíl od religionistiky) zřídka zpochybňovaným předpokladem lze ilustrovat na několika konkrétních př́kladech vycházejících z mých indických pobytů. ${ }^{17}$ Indie je zajímavá v jednom zásadním ohledu: zatímco v evropské imaginaci žije jako „posvátná“, „mystická“ země, čehož bohatě využívá především indický, evropský, japonský, australský a americký cestovní průmysl, kategorie posvátna nebo náboženství v jejích jazycích - kromě angličtiny - nenalezneme.

Abych předešel nedorozumění ze strany těch, kdo obřady v chrámech automaticky spojují s posvátnem a/nebo je bez dalšího dotazování samozřejmě klasifikují jako projevy „náboženství“, zdůrazním, že v mých osmnácti letech mně jako turistovi v Indii posvátné připadalo vše; jiným termínem jsem nedokázal postihnout dění na místech, na nichž jsem se často zdržoval, na nichž stojí řada chrámů, váží se k nim významná, mytická vyprávění a obvykle se nazývají tírtha (tj. doslova „brod“), nebo v šaktických tradicích šakti píth

17 Ten hlavní probíhal v rámci mého disertačního výzkumu od prosince 2006 do ř́jna 2007, kdy jsem měl možnost pobývat díky grantu ICCR (Indian Council for Cultural Relations) na univerzitě v maráthském Púné. Na tento pobyt navázal krátký návrat v prosinci 2009 až únoru 2010; v tomto př́padě se nejednalo o pobyt výzkumný. Výzkumný nebyl ani pobyt, který proběhl mezi prosincem 1997 a dubnem 1998, kdy jsem ještě ani nevěděl, že se někdy budu zabývat studiem náboženství. Pro ujasnění některých souvislostí však není od věci jej také zmínit. 
(tj. „místa síly“). Posvátné věci ale najednou zcela zmizely, když jsem si osvojil sanskrt a začal komunikovat v hindí. „Posvátná řeka Ganga“ se najednou ukázala být prostě Gangá Mátá („Matka Ganga“), „posvátný okrsek“ chrámu či ášramu byl najednou prostě dhám (tj. „obydlí“ či „,poutní místo“), „posvátná koupel“ byla prostě snán (tj. „koupel“, úplně stejně jako koupel doma v koupelně). Problém se ukázal být i s dvojzrozeneckou šn̆ůrkou, v angličtině standardně označovanou výrazem ,sacred thread“ (napríílad Monier-Williams 2004: 840; McGregor 2005: 356), přestože v jejím názvu jadžňópavita není po „posvátném“ ani stopa. Znamená totiž prostě „ovázaný (upavíta) obětí (jadžňa)“ a odkazuje ke skutečnosti, že ten, kdo je šňůrou obdařen během iniciace, se tím stává plnohodnotným členem společenství Árjů především v tom smyslu, že může vykonávat domácí védské oběti (jadžňa) a být oženěn a pohřben (Michaels 2005: 73) v souladu s dvojzrozeneckou sanskrtskou védskou tradicí.

$\mathrm{Z}$ toho, co se $\mathrm{k}$ oddělení posvátného a profánního říká $\mathrm{v}$ indické literatuře, je pak patrně nejpřípadnější následující poznámka Nirada Choudhuriho (1979: 20) k absenci sanskrtského ekvivalentu pro řecký výraz hagios a latinské sacer a sacrum:

Jsem si vědom, že odvozené adjektivum jadžata, jež védy často připisují bohủm a doslova znamená ,ti, kdo jsou hodni obětí“" získalo v moderních sanskrtských slovnících význam svatého (holy) či božského (divine). Avšak nejsem schopen zjistit proč.

Co tím chci říct? Že ve chvíli, kdy jsem začal komunikovat prostřednictvím indických jazyků, nebylo po emické binární opozici, kterou Durkheim považoval za univerzální, najednou ani památky, zmizela. Místo ve světě „,posvátného a profánního“ jsem se začal pohybovat spíše ve světě plném pravidel, která jsem si jako cizinec (angréz či vidéši) chtě nechtě musel osvojovat: že ušetřit jedno ohnutí v zádech a zasouvat plynovou bombu pod postel nohou se nepatří, protože na bombu se montuje vařič a na tom se pak připravuje jídlo; že po vypití čaje (s mlékem) bych neměl recitovat Gítu, nebo bych si měl vypláchnout ústa; že psů bych se v žádném př́padě neměl dotýkat; že dotýkat bych se neměl ani určitých lidí - at' už těch, jež bych mohl znečistit, tak těch, kteří by mohli znečistit mě; že během zatmění slunce bych neměl jíst; že bych vůbec neměl jíst přii dlouhé cestě vlakem železniční vařené jídlo, ale radši si vzít doma nebo v ášramu ${ }^{18}$ prripravené parathy (placky) a suché sabdži (zeleninové kari), protože železniční vařené jídlo ,je pro jogína nestravitelné“ a nečisté.

Kromě toho to byl ale svět, v němž všechny tyto předpisy byly velmi relativní: co jsem si mohl dovolit ve vztahu $\mathrm{k}$ lidem $\mathrm{s}$ určitým statusem (nebo jen osobním přesvědčením), jsem si nemohl dovolit $\mathrm{k}$ lidem jiným; co jsem mohl činit, když v ášramu právě nepobývala jistá osoba, ${ }^{19}$ jsem nemohl činit, když tam pobývala; co jsem si nemohl dovolit (v projevech osobní úcty a s nimi spjatými formami tělesného kontaktu) v ášramu samotném, jsem si mohl dovolit za jeho branami nebo v domácnostech rodin osob v ášramu žijících. Samozřejmě že se tato pravidla také měnila $\mathrm{v}$ různých komunitách. Takže zatímco $\mathrm{v}$ malém komunitním

18 Většinou zde hovořím o zkušenostech získaných během pobytů v tradicionalistickém jógovém ášramu (v němž jsem byl jediným cizincem) ve vesnici Saváín v severoindickém státě Uttarpradéš v obdobích únor-březen 2007, červenec-srpen 2007 a prosinec-leden 2009.

19 Jednalo se o Mátá dži (Matku), guru-sestru mužů, kteří představovali jakousi elitu ášramového společenství, protože byli př́mými žáky posledního zesnulého gurua. 
ášramu byla má účast (jakožto cizince) na př́ípravě jídla vyloučena, v největší dillíské gurudváře nebo v mamutím ${ }^{20}$ haridvárském ášramu společenství zvaného Gájatrí parivár (Rodina Gájatrí $)^{21}$ naopak byla s nadšením vítána.

Jakkoliv jednoznačně zmizely „posvátné“ věci, s Durkheimovými věcmi „zakázanými“, jak naznačil předchozí odstavec, to je zjevně jinak. Bez jadžňópavity prostě védské rituály legitimně vykonávat nelze, nelze, nebo není radno, se dotýkat řady věcí, které jsou gandá (tj. „špinavé“"), nebo je vykonávat atd. „Není radno“, protože nerespektování takového zákazu, nebo spíš nedoporučení, může mít nepř́ijemné praktické důsledky. Den poté, co jsem jednou vstoupil do svatyně, kam jsem měl vstup zapovězen, jsem byl dotázán, zda jsem vstoupil do svatyně, a na odpověd', že ano, mi bylo nikoliv nepřátelsky, ale velice jasně vysvětleno, že ,jogíni vnímali nečisté síly“ a že už to tedy nemám opakovat. Bývalý český oddaný Kršny, který byl na pouti v Uríse, kde stojí slavný Džagannáthův chrám, byl odkázán, jako ostatní jeho „nečistí“ kolegové ze Západu, na pohled do chrámu pouze ze střechy nedaleké budovy. $\mathrm{V}$ interview mi však vyprávěl př́hodu neštastníka, který to nerespektoval, byl přistižen v blízkosti Džagannáthovy kuchyně a následně surově zbit, protože celá várka prasádu musela být kvůli jeho nečistému pohledu znehodnocena. Nečistota a zákaz a s ním spjaté sociální distinkce (viz Michaels 2005: 73nn, 92nn) k sobě mají velice blízko. To, co je člověku ještě dovoleno, zároveň vymezuje, kam patř́i.

To nás ale staví před problém. Které z těch četných zákazů, př́kazů, omezení, o nichž jsem hovořil, se týkají posvátného, a jsou tedy „náboženské“, a které jsou omezeními jiného

20 Výrazy „největši““ a „mamutí“ sugerují dojem, že velikost je zásadním faktorem určujícím vztah k cizincům. Není tomu ale tak. Jde spíše o to, že zatímco zmíněný jógový ášram je výrazně vázán na relativně omezený okruh bráhmanských rodin, jak sikhské gurudváry, tak haridvárský Šántikuňdž jsou součástí masových globálních společenství. Mnohem větší význam v nich také hraje ideologie rovnosti, které odpovídá i inkluze lidí různého sociálního původu do jednoho rituálního systému. V jógovém ášramu v Saváínu je jógový důraz na čistotu interpretován v souladu s bráhmanským pojetím čistoty, a tedy i s udržováním sociálních distinkcí prostřednictvím pravidel sociálního styku a doteku. Do ášramu proto nemají přístup šúdrovské kasty, například krejčí. Cizinci jsou omezeni především nemožností vstupovat do gufy (poustevny, v níž žil guru - avatár boha Šivy, který je na začátku řetězce tradice) a podílet se na vaření. To ale neznamená, že by tato omezení byla známa i obyvatelům, kteří v ášramu nežijí trvale. Také je nelze zobecnit, protože v rišikéšském ášramu stejné tradice i cizinec, jako jsem já, může navštěvovat místnost, v níž zde přebýval poslední guru této tradice. Ani v něm jsem se ovšem nemohl účastnit př́pravy jídla. Předpisy týkající se čistoty stravy se v tomto ohledu jeví jako nejvýznamnější, jakkoliv i ty pouze $\mathrm{v}$ ášramech, nikoliv nutně $\mathrm{v}$ domácnostech rodin, které se $\mathrm{k}$ této tradici hlásí. I někteří mladší obyvatelé ášramu jsou nicméně vůči tomuto pravidlu kritičtí a rádi by prosadili praxi založenou na představě univerzální rovnosti lidí, respektive oddaných. Důvod nečistoty cizinců mi byl vysvětlen následovně: každý cizinec někdy jedl krávu.

21 Můj pobyt v uvedené dillíské gurudváře se uskutečnil v březnu 1998. Do gurudváry mě tehdy přivedlo to, že jsem přišel o peníze i o pas a několik dní jsem byl tedy nucen využívat pro mě tehdy nejdostupnější charitativní podporu. V haridvárském Šántikuňdži jsem krátce pobýval na konci ledna 2010. Příznačné je, že můj pobyt zde byl dojednán jedním z obyvatel jógového ášramu $\mathrm{s}$ jeho vzdálenými př́ibuznými, kteří zde trvale žijí. Cílem tohoto opatření bylo zajistit mi pro pobyt v Haridváru „,̌istéc“ místo s ,čistou“ stravou. 
typu? Je zákaz jíst špinavýma (gandá) rukama náboženský? Je náboženským zákazem dotýkat se lidí s leprou nebo žebráků? Nebo je jím spíš to, že se úřednice univerzitního oddělení pro zahraniční studenty nemůže dotázat na imigračním úřadu, jestli náhodou neztratili složku íránského studenta, který již několik měsíců neobdržel vyrozumění ohledně povolení k pobytu? Takže jaké zákazy jsou náboženské a jaké nenáboženské?

Koncept zákazu nám zjevně k vymezení náboženství nestačí, pokud zároveň nemáme po ruce emickou klasifikaci věcí na posvátné a profánní; a tu nemáme, navzdory Durkheimově domněnce, že se jedná o univerzálii. Toto pak platí i tehdy, když v indickém kontextu zůstaneme u zákazů vztahujících se k věcem označeným jako špinavé (gandá). Kategorie „špinavého“" totiž i v hindí, stejně jako třeba v češtině nebo angličtině, mísí dohromady záležitosti medicínsko-hygienické se záležitostmi „sociálními“, což pro čtenáře Mary Douglasové (1992: $34 n n)$ není ničím překvapivé. Problém čistoty/nečistoty je jednoduše záležitostí klasifikace a znamená $\mathrm{v}$ zásadě př́tomnost čehokoliv na místě, kde to, podle toho či onoho jedince, skupiny nebo textu nemá být (viz Michaels 2005: 186; Michaels zde navazuje na analýzy Douglasové 1992: 35nn). Takže jediný způsob, jak oddělit „náboženské“ a „nenáboženské“ zákazy, je mít jednoznačnou etickou definici toho, co znamená být „náboženský““.22 Poskytuje Durkheim nějaký vhodný nástroj $\mathrm{k}$ řešení tohoto problému? Říká, co, kromě zákazů, činí věci posvátnými?

K tomu Durkheim neříká vůbec nic. Ale objasňuje, jakou funkci náboženské zákazy plní: umožňují zvládat jeden paradox. Tím paradoxem je skutečnost, že posvátné a profánní jsou sice „absolutně“ odlišné (Durkheim 2002: 47), ale přesto je posvátnými věcmi v podstatě zaplněn celý svět (tamtéž: 167nn) a profánní věci (lidé) s nimi mohou vstupovat do kontaktu (tamtéž: 47nn). Právě existence pravidel týkajících se jejich styku (tj. to, co nazývá „negativní rituály“; tamtéž: $327 \mathrm{nn}$ ) umožňuje navzdory vzájemné propletenosti udržovat distinkci. Jinými slovy, posvátné věci jsou věci zakázané a funkcí zákazů je oddělovat posvátné věci od profánních. Durkheim jen dodává, že zákony, jež nás tu zajímají, jsou ty, které se vztahují k „posvátným věcem“ nebo jsou součástí „náboženských rituálư“. S uvedeným problémem nám toto tvrzení tedy v ničem nepomůže. Otázka pak spočívá spíš v tom, jak je možné, že tato cyklická argumentace Durkheimovi vůbec nepřekážela, jak to, že během své práce nenarazil na neřešitelné problémy?

Odpověd’ na ni souvisí s tím, jak Durkheim vymezil povahu společnosti, jíž se zabýval. Šlo o „nejprimitivnější společnost“ a v ní pak o „elementární formy náboženského života“, nebot' předpokládal, že díky takovému zaměření pozornosti dokáže izolovat z věr a praktik

22 Výmluvnou ilustrací této skutečnosti je též následující událost, jež se odehrála v podmínkách běžné české domácnosti: Petra [jedná se o pseudonym] se v mé prŕítomnosti chystala ostř́hat si nehty na nohou. Za tím účelem si jako podložku na odpad přinesla staré noviny. Shodou okolností se jednalo zrovna o zvláštní vydání Mladé fronty Dnes k události úmrtí prezidenta Václava Havla: „Na Havla si asi nehty stříhat nemůžu.“ „Tak si jdi pro nějaké jiné noviny.“ Na dalších přinesených novinách byla pouze fotografie rektora jedné české univerzity. Na ně již nebyl problém si nehty ostříhat. Je tato prevence znečištění fotografie Václava Havla tělesnými zbytky, které v naší společnosti jinak nebudí žádné zvláštní pozdvižení, rituálním náboženským aktem? Je Václav Havel na fotografii otištěné v den jeho úmrtí „nadpřirozenou“ bytostí? Pokud ano, v čem jeho „nadpřirozenost" spočívá? 
lidí to, co je pro náboženství skutečně podstatné (Durkheim 2002: 106). Ovšem tento předpoklad doplňoval předpoklad jiný, ten, že ,primitivní společnost““ je zcela ovládána náboženstvím. Durkheim tedy při studiu totemismu neměl důvod se ptát, které víry a rituály jsou „náboženské“ (respektive vztažené k „posvátným věcem“) a které nikoliv, které zákazy jsou „náboženské“ a které jsou nějakým způsobem jiného druhu. Automaticky předpokládal, že náboženské jsou prostě všechny zákazy. To bylo ostatně v souladu s tím, jak pojímal dělbu práce a typ solidarity pro takovou ,primitivní“ společnost charakteristické.

Podobným směrem jej vedla i jeho analýza: Totem je v zásadě materiální symbolizací, médiem, na něž jsou přenášeny pocity spojené s respektem, morálním tlakem, ale i podporující silou, pocity, jež sdílíme jakožto členové společenství. Je to tedy médium zosobňující vnější tlak, jímž společnost jakoby zvnějšku omezuje naše vlastní chtění, i podpora, již nám zajišt'uje skutečnost, že jsme její součástí, částí něčeho většího, co nás svou mocí přesahuje (Durkheim 2002: 229nn). Je to materiální (zástupný) předmět, do něhož je vtěleno naše vědomí, že jakožto př́slušníci společnosti nejsme zcela svobodní, ale jsme omezovaní jejími pravidly, že své okolí sice každodenně utváríme, ale zároveň čerpáme z nahromaděného bohatství poznání, prostředků komunikace i technologie, které jsme sami nevytvořili (Durkheim 2002: 243nn).

Z uvedeného plyne, že Durkheim nepotřeboval jasně vymezit vztah náboženství jakožto kategorie nižšího rrádu a společnosti jakožto kategorie obecnější, protože v kontextu, v němž se náboženství v Elementárnich formách věnoval, tyto kategorie věcně splývaly. Pak je ovšem třeba se ptát, jak je možné, že na Durkheima navzdory tomu mohli navázat teoretici sekularizace s otázkou po změně role náboženství v moderní společnosti. Jak jsme viděli, část odpovědi nám dává jejich víra $\mathrm{v}$ předsudek ohledně sdílení jednotného společenského/ náboženského vědomí lidmi v předmoderních společnostech, jež přímo souvisí s domýšlivostí po-osvícenské a koloniální evropské intelektuální tradice. Jiným důležitým důvodem je dědictví problémů formulovaných Maxem Weberem a třetí spočivá ve zvláštní interpretaci Durkheimem užitých výrazů „církev“ a „morální společenství“.

\section{Církev jako morální společenství}

Co se týče pojmu pro označení společenství, které sjednocuje lidi prostřednictvím věr a praktik vztažených $\mathrm{k}$ posvátným věcem, způsobuje Durkheim svým dědicům problémy tím, že použil výraz „církev“ (Église). Zdá se, že pro něj samotného byl tento termín především odkazem k pojmu morálního společenství. Jak jsme však viděli u Grace Davieové a jak již před mnoha desetiletími upozornil Thomas Luckmann (1967), sociologický hlavní proud upřednostnil před pojmem „morálního společenstvi“ pojem organizace pečující o teologickou reflexi tradice a svěřené statky a $\mathrm{v}$ různých dobách si různou měrou a různým způsobem nárokující reprezentovat své členy a v některých ohledech určovat, jací by měli být, či v př́padech výjimečnějších dokonce vykonávat morální dozor s možnostmi perzekuce. Přitom pojem členství, jak jsem ukázal výše, a jeho praktické důsledky jsou v této tradici velice rozmanité a nejasné a to, nakolik se tito reprezentující lidé cítí zavázáni žít způsobem, jakým by podle zástupců této organizace (at' už jsou jimi lidé, tiskoviny nebo elektronické dokumenty) žít měli, prredstavuje samo o sobě celé klubko dalších komplexních problémů. 
Každopádně ona záměna organizace za „morální společenství“ má jeden zásadní důsledek: upuštění od durkheimovských otázek po sociální soudržnosti. Durkheimovská sociologie, která je sociologií proto, že je vedena otázkou po tom, co drží společnost pohromadě, po tom, jak se ustavuje sociální řád, se tak mění ve vědu o náboženství, která vlastně ani tak úplně sociologií není, protože fundamentální sociologický zájem se z ní vytratil. Sociologie náboženství jakožto sociologie církví klade otázku po sociálním rrádu jen zdánlivě. Předpokládá totiž a priori, jak jsme to viděli u Grace Davieové, že řád se církevním učením či prostou existencí církve ustavuje sám od sebe, tajemnou schopností „přitažlivosti církve“ zajistit s ním konformitu. Jak už jsme ale viděli, (mikro)historici i antropologové upozorňují, že takový postoj znamená propadnutí velké a nebezpečné iluzi.

Toto je sice problém, ale v zásadě je řešitelný a jeho řešení lze z výše uvedených analýz vyvodit. Durkheim zůstal navzdory některým nedůslednostem inspirativní pro sociologickou teorii tím, že se, důsledně vzato, náboženstvím nezabýval. Spíše podrobně sledoval, jak je ustavována a udržována sociální soudržnost ve společnosti, o níž zároveň předpokládal, že je ze své podstaty náboženská. U toho lze zůstat i v př́ípadě naší současné společnosti, jakkoliv ji považujeme za sekulární. I v jejím rámci se lze zabývat prakticky tímtéž, čím se zabýval Durkheim, jen s tím rozdílem, že škrtneme pojem náboženství. Ne proto, že my jsme sekulární, nenáboženští, ale proto, že daný „výraz“ způsobuje zbytečný zmatek a odvádí pozornost od podstatných věcí, jež stojí za pečlivé studium. Ten pojem nese při nejlepších snahách př́liš těžké břemeno snahy o vykázání určitých autorit a určité organizační struktury na prahu moderní doby politicky do náležitých mezí. Jinými slovy, celý kategoriální komplex spojený s pojmem náboženství zakládá významné politické asymetrie, což není překvapivé ani problematické. Problematické je však to, že tyto asymetrie přenáší do analýzy, která ale nemá za cíl tyto asymetrie udržovat v chodu, ale spíše jim chce rozumět. Proto lze problémy způsobované analytickým užíváním konceptu náboženství formulovat také jako problémy plynoucí $\mathrm{z}$ absence symetrického př́stupu. ${ }^{23}$

\section{Závěr: Symetrický přístup a sociologie bez „náboženství“}

Odborníci zabývající se náboženstvím jsou tedy těžko schopni rozumět uspořádání svých vlastních společností natolik, nakolik jsou politické instituce těchto společností uspořádány v souladu se stejnými kategoriemi a jejich vztahy, s jakými pracují také tito badatelé jako se svými samozřejmými východisky. Kategorie náboženství a celá sít' dalších s ní svázaných kategorií jako sekulární, přirozené/nadpřirozené, empirické/nadempirické, posvátné/profánní, racionální/iracionální, veřejné/soukromé je propojena velmi specifickými vztahy a je zcela zásadní součástí tohoto uspořádání. Náboženství a věda v tomto uspořádání např́íklad nejdou dohromady proto, že jedno je iracionální, soukromé, posvátné, týkající se nadpřirozeného

23 Zdeněk Konopásek a Jan Paleček (2006) převedli do češtiny tento př́stup výrazem př́istup „,věrícný“. Jednak přístup „věřícný“ znamená něco radikálně odlišného než přístup ,věřící“, který, jak také podrobně rozebírají, symetrický není, jednak tento výraz pro mé potřeby na tomto místě, jakkoliv je velice výstižný, alespoň na první pohled problematiku př́liš zužuje. Proto se zde podržím výrazu ,symetrický“. 
a vztažené $\mathrm{k}$ nadempirickému, zatímco druhé má charakteristiky v rámci uvedeného systému opozic přesně opačné. Co je ještě důležitější, tato distribuce vlastností není považována za společensky ustavený konsensus, ale za důsledek přirozeného řádu věcí, který jsme konečně objevili a ve své politice a ve své produkci vědění se jím řídíme. A právě proto, že tyto věci jsou tak ,přirozené“, je pro vědu v takové společnosti obtížné vyvodit důsledky z toho, že navzdory všemu je toto uspořádání výsledkem konkrétních jednání v konkrétních historických dobách a jako takové je jen jednou z nekonečně mnoha možností, které se tedy ustavily jako fakticky skutečné ve zcela konkrétních společnostech, a v tom smyslu jsou tedy relativní, parciální a dočasné.

Jako faktické uspořádání věcí v konkrétních společnostech jej sociální věda musí také brát. To ale zároveň znamená, že z něj nemůže jako z univerzální přirozené danosti vycházet, pokud si nechce systematicky znemožňovat vzájemně relativní srovnání této skutečnosti se skutečnostmi jinými, srovnání, jež by umožnilo toto uspořádání podrobně analyzovat tím, že zviditelní jeho rozličná specifika a zdůrazněním jejich nesamozřejmosti umožní klást preciznější analytické otázky. Preciznější ne v tom smyslu, že takové uspořádání objevíme; preciznější v tom, že se dokážeme podrobněji, na pozadí toho, že se zbavíme představy vlastní výjimečnosti, ptát, jaké má konkrétní praktické důsledky a jak je konkrétně (re)produkováno. Zbavit se představy vlastní výjimečnosti ale vzato do důsledku znamená, že tato už nebude fungovat jako absolutní měřítko, v jehož světle jsme méně náboženští, čímž vlastně myslíme více racionální a svobodní. Nejde vlastně o nic jiného než o požadavek symetrického přístupu.

David Bloor, který ne zcela náhodou tento požadavek formuloval v rámci sociologie vědy, tedy sociologie, která se zabývá mimo jiné tím, jak se věci stávají „,přirozenými“, to formuloval následovně: „Požadavek symetrie [...] nás zavazuje hledat stejný typ př́icin pro pravdivá stejně jako chybná, racionální stejně jako iracionální přesvědčení، (Bloor 1991: 175). Tento požadavek je tak snadno pochopitelný jako naše pozorování, že k tomu, abychom někoho přesvědčili o nějakém faktu, je potřeba mnohem víc než působení jeho prosté, přirozené „faktičnosti“; konkrétně je třeba obtížné práce, v níž svoji roli hrají způsoby argumentace, postupy dokazování a dosahování empirické evidence, postupy demonstrace, způsoby výchovy atd. Nebo také že žádná skutečnost není evidentní sama sebou, ale získává evidenci skrze aktivity, v nichž jsou mobilizovány další již ustavené evidence i stejně ustavené nebo vhodně vystavěné nové či inovované postupy, jimiž se $\mathrm{v}$ daném kolektivu ${ }^{24}$ evidence

24 Výraz „kolektiv“ by zde měl mimo jiné naznačit, že také neexistuje nic jako obecně moderní evropský způsob dosahování evidence ve smyslu vázanosti těchto způsobů na nějaké tzv. kulturní okruhy, pokud o kultuře uvažujeme v prosté vazbě na geografické hranice a zároveň zapomínáme na to, že kultura je záležitost především sdílení, a tedy vyžaduje kontakt, komunikaci a interakci. V tomto smyslu jsou např́íklad způsoby dosahování evidence při parlamentním a vládním politickém vyjednávání na straně jedné, stranické mobilizace voličstva na straně druhé, sociologické přesvědčování v odborném časopise na straně třetí a přesvědčování ohledně faktické povahy zážitků při meditaci v buddhistické skupině na straně čtvrté velmi odlišné. Aniž by z toho plynulo, že jsou tyto způsoby zcela mimoběžné a neexistují mezi nimi žádné vazby. Karin Knorr Cetina (1999: 3) hovoří o různých „epistemických kulturách“ dokonce i v rámci samotné současné západní vědy. Naráží tím na „odlišnosti v architekturách empirických přístupů, specifických způsobech konstruování referentů, zvláštních ontologiích nástrojů a odlišných sociálních ustrojeních“. 
vykazuje. Zásadní význam pak má to, že tyto aktivity jsou empiricky studovatelné, a pokud máme analyzovat sociální řád konkrétní společnosti, tak je pochopitelně také empiricky studovat musíme. Přesto je společenskovědní praxe vzdálena tomuto přístupu natolik, nakolik je vzdálena ochotě přiznat racionálnost věcem zdánlivě iracionálním nebo empiričnost věcem „,nadempirickým“. Nakolik je vzdálena představě, že duch, který posedl nemocného, ${ }^{25}$ je pro šamana stejně empirickým faktem, jako je jím ledvinová kolika pro západního lékaře vybaveného ultrazvukem. Jenže pak se nelze divit, vrátíme-li se opět ke Grace Davieové, že dostupná data naznačují, ,že se děje ještě něco jiného, možná velice zajímavého, ale nelze zjistit co".

A právě v této neschopnosti vězí velká část praktických problémů s pojmem, jakým je „náboženství“، Právě tato neschopnost akceptovat empirickou danost a reálnou faktičnost posedlosti duchem pro šamana nám znemožňuje studovat šamanské léčení a moderní lékařské léčení prostřednictvím stejných pojmů, hledáním stejného typu prŕčin, jak požadoval Bloor. „Náboženství“ této nesymetrické praxi pomáhá právě tím, že a priori činí šamanské léčení a moderní lékařské léčení nesouměřitelným. Obě činnosti umist’uje do zcela jiné oblasti lidského/společenského života - jednu do „náboženství“, druhou do „vědy“, respektive vědecky fundovaného lékařství -, a znemožňuje tak ve vztahu k oběma klást stejný typ sociologických otázek, a to dokonce navzdory tomu, že jsme jinak schopni obě činnosti konceptualizovat jako „léčení“. A umist’uje je, dodejme, do těchto dvou odlišných sfér činnosti nikoliv proto, že by šaman nevznášel, stejně jako moderní lékař, empirické nároky na to, že fakticky vidí nepatřičného ducha a provádí s ním operace, které, bude-li úspěšný, duchovi znemožní způsobovat to, co způsobuje, což bude znamenat, že u nemocného zmizí (opět empiricky) vnímatelné známky nemoci. Činí tak pouze a jenom na základě toho, že zatímco modernímu lékaři sociolog prostě přiznává právo si tuto empiričnost nárokovat a věří mu, jakkoliv objekty, které mu takový lékař popisuje na snímku z ultrazvuku, jsou pro jeho necvičené oko stejnými halucinacemi jako duch posedlého, tak šamanovi toto právo nepřiznává. Jinými slovy, činí tak jenom proto, že šamana, v důsledku jeho zařazení do oblasti náboženského, vnímá zároveň jako figuru iracionální, mystickou, komunikující s nadpřirozeným světem, a tedy v ,„prrirozeném“ světě (světě faktů) nedůvěryhodnou, zatímco lékař je stejně racionální, empiricky založený, a tedy i důvěryhodný jako sociolog sám. ${ }^{26}$

25 Posedlostí, respektive zacházením s určitými empirickými př́znaky v rámci dvou epistemických kultur, jakými jsou psychiatrie a pastorální péče, se zabývají právě Konopásek s Palečkem jednak $\mathrm{v}$ již uvedeném programovém textu „V moci d’ábla“ (Konopásek a Paleček 2006), ale též v dílčích empirických studiích „Apparitions and Possessions as Boundary Objects“ (Konopásek a Paleček 2012) a „The Principle of Symmetry From the Respondents’ Perspective“ (Konopásek a Paleček 2011). Velice stručné shrnutí celého Konopáskova a Palečkova projektu studia skutečností na hranicích medicíny a teologie, respektive náboženské víry, poskytuje článek Zdeňka Konopáska „V čem spočívá pravda náboženské skutečnosti?““(Konopásek 2010).

26 V této souvislosti stojí též za zmínku jeden z důležitých závěrů konferenční přednášky Zdeňka Konopáska „Religion in Action: When Theology Meets Latourian Science Studies“ (Towards a Symmetrical Approach: The Study of Religions After Postmodern and Postcolonial Criticism, FF MU, Brno, 30. 11. 2012). V přednášce byl zveřejněn patrně poslední významný okruh závěrů z Konopáskova projektu zaměřeného na průzkum hranic mezi klinickou psychiatrií a pastorální 
Příklad s hidžábem ze začátku textu pak působí právě naopak: identifikace muslimského šátku s islámem a islámu s náboženstvím na nás působí tak silně a samozřejmě, že je pro nás skoro nemožné si představit, že by jeden šátek s druhým nemusel mít vůbec nic společného. Nedokážeme si představit, že to, co je $\mathrm{v}$ jedné situaci součástí artikulace menšinové identity, je $\mathrm{v}$ prŕpadě druhém třeba součástí pocitu vymanění se všeobecnému policejnímu dozoru a trvalé hrozbě perzekuce. Zde nám tedy samozřejmé propojení pojmů jako „islám“, „hidžáb“ a „náboženstvi'“ naopak znemožňuje vidět distinkci, jež by nám za jiných okolností připadala na první pohled evidentní.

Právě z toho důvodu je tak zásadní do zkoumání ŕád, jaký je konstruovaný okolo pojmu náboženství, a priori nevnášet, ale naopak vždy znovu od začátku pomalu stopovat, jakými praktikami jsou uspořádávány jaké světy $\mathrm{v}$ poli, které zkoumáme. To však znamená, že zrovna pojem náboženství a všechny kategoriální vztahy, které spolukonstruuje, je nezbytné odstranit z cesty. Koneckonců už Foucault (2002) ukazoval, jak je zbavení se samozřejmě prrijímaných celků strukturujících to, co teprve chceme poznat, důležité pro analytickou práci, v níž nás naopak primárně mají zajímat „fakta diskursu“. Doslova říká:

Lze bez dalšího prozkoumání přijmout rozlišení hlavních typů diskursů, anebo rozlišení forem či žánrů, která proti sobě staví vědu, literaturu, filosofii, náboženství, historii, fikci atd. a která z nich vytvárejí cosi jako velké historické individuality? [...] [A]ni literatura, ani politika, ani filosofie a věda neartikulovaly v 17 . nebo 18 . století pole diskursu tak, jako tomu bylo v 19 . století. V každém př́ípadě jsou sama tato rozdělení - at' naše vlastní nebo ta, která jsou soudobá zkoumanému diskursu - vždy kategoriemi reflexe, principy klasifikace, normativními pravidly, institucionalizovanými typy: to, co si mezi jinými naopak zaslouží být analyzováno, jsou fakta diskursu. (Foucault 2002: 37)

Foucault dokonce přesně popisuje, co tímto postupem získáme:

[O]svobozením těchto faktů [diskursu] od všech seskupení, která mají za cíl vypadat jako přirozené, bezprostřední, univerzální jednotky, budeme schopni popsat jiné jednotky, ale tentokrát pomocí souboru kontrolovaných rozhodnutí. (Foucault 2002: 48; kurzíva MF)

S odkazem na výše uvedené to lze napsat také tak, že teprve za této podmínky můžeme prestat zkoumaná data výrazně disciplinovat, a místo toho je naopak nechat mluvit třeba i proti normativním pravidlům, jež považujeme za samožrejmá, a prostřednictvím toho, co vypovídají výpovědi, o něž se zajímáme (at' již mají povahu faktů diskursu v užším smyslu,

péčí. Jednou ze zásadních věcí, které zde byly sděleny na základě výzkumu zjevení Panny Marie u obce Litmanová na Slovensku, bylo to, že kumulování empirické evidence ohledně událostí spojených se zjevením bylo pro ustavování poutního místa a pravdy události zjevení velice zásadní. Zdeněk Konopásek se ve svém příspěvku snažil zdůraznit, že shromažd'ování a ověřování faktů představuje zásadní aspekt „náboženství v procesu utváření“ poněkud analogickým způsobem, jakým představuje zásadní aspekt ve vědě v procesu utváření. Chtěl tak poukázat na to, že tento aspekt utváření vědy, který Latour považuje za významný při studiu vědy, ale sám jej poněkud marginalizuje při studiu lidské komunikace $\mathrm{s}$ bohem, je i v této oblasti nesmírně důležité studovat, alespoň tedy tam, kde se nesetkáváme s ještě hotovými náboženskými skutečnostmi (jako právě zjevení Panny Marie), ale s jejich budováním s ještě nejistým výsledkem. 
nebo zaznamenaných jednání a interakcí), teprve hledat orientaci v uspořádáních, která spoluutváríi. $^{27}$

V tomto smyslu může teoreticky nosná analytická práce, jež by nahradila „předvádění rituálư“‘, o němž hovoří Fitzgerald (2003), začít teprve tím, že si zakážeme užívání pojmu „náboženství“ a kategoriální struktury, která jej obklopuje. Tento zákaz má dva aspekty. Tím prvním se řeší nedůsledně zdůvodněný způsob zahrnování rozličných věcí pod jednu zdánlivě jasnou kategorii; tím druhým, obtížněji uskutečnitelným, se rozrušují hranice, které a priori oddělují náboženské a nenáboženské věci, čímž znemožňují, aby se analyticky dostaly k sobě.

První z uvedených aspektů lze uskutečnit relativně snadno, protože jde vlastně o pouhý zákaz užívat výraz „,náboženství“ jinak než jako bezprostřední odkaz k faktu diskursu, tedy zcela konkrétní analyzované výpovědi, v níž se objevil. Dủležité v tomto ohledu je neusnadňovat sami sobě práci tím, že výrazy jako „náboženství“ či „náboženský“ (a jim blízké výrazy jako „posvátný“, „nadpřirozený“ atd.) použijeme jako stafáž tehdy, když nevíme, co přesně, na co jiného a jakým konkrétním způsobem působí, nebo když nedokážeme dostatečně konkrétně a jasně popsat vlastnosti nějakého objektu. Jinými slovy, když děláme nějakou sociologickou obdobu situace, kdy archeologové najdou neznámý předmět nejasné funkce a prohlásí jej, právě proto, že neví, o co jde, za předmět „,posvátný“، Nicneříkající „náboženské faktory“ nám nepomohou s pochopením vůbec ničeho.

S praktickým uskutečněním druhého uvedeného aspektu je to těžší, protože v případě oddělování náboženských věcí od věcí jiných působí, přibližně způsobem ilustrovaným na příkladu šamana a lékaře, celá pojmová struktura, jež „náboženstvi““ obepíná, a to na mnohem hůře reflektovatelné úrovni. Na té, k níž Foucault odkazuje, když mezi inspiračními zdroji svého pojetí diskursivní analýzy zmiňuje lacanovskou psychoanalýzu a pojem nevědomí. Zde bohužel nelze doporučit jednoduchou techniku analogickou předchozímu zákazu užívání výrazu „náboženstvi'“ a jeho odvozenin. Spíš jde o to, vytvořit si reflexivní kontrolku, která začne svítit tehdy, když se nám začne jevit jako absurdní zcela vážně a ve zcela souměřitelných pojmech srovnávat šamanskou léčebnou a vědecky medicínskou praxi. Něco jako: čím víc absurdní se to zdá, tím více to stojí pro začátek aspoň za malý myšlenkový experiment. Principiálně lze totiž smysluplně cokoliv srovnávat s čímkoliv. Relevance srovnání nespočívá ani tak v tom, co srovnáváme, ale $\mathrm{v}$ důvodech, které nás vedou $\mathrm{k}$ tomu, proč to srovnáváme, a v tom, co doufáme, že tím získáme.

I v tomto nám Durkheim poskytl aspoň několik drobných vodítek. Sám například upozornil na to, že totemismus je vlastně spíš problémem sociologie rodiny než sociologie náboženství (Durkheim 2002: 116), protože podstatná je zde otázka organizace klanu. O systému totemického náboženství vlastně mluvil jen v tom smyslu, že jednotlivé totemy v zásadě odráží společenské opozice v kmeni, což předpokládá, že jednotlivé klany „,věří“ v totemy všech klanů ostatních. Jednotlivé klanové totemismy jsou tak strukturálně napojeny na celý rodinně-organizačně-náboženský systém kmene (tamtéž: 171nn). Kromě toho ale např́klad už sám Durkheim názorně ukázal, že nepřekonatelná není ani hranice mezi vědou, politikou a náboženstvím a vědecký a politický provoz lze po mnoha stránkách analyzovat stejným

27 Podrobněji viz kapitoly o různých zdrojích nejistoty v Latour (2005). 
způsobem, jakým analyzoval náboženství, respektive lze v nich identifikovat stejné sociální funkce a mechanismy, a s ohledem na takový typ poznání také různé politické, náboženské a vědecké instituce vzájemně symetricky srovnávat (tamtéž: 260nn, 237).

Chci tím říct, že nic nebrání tomu, abychom analyzovali uspořádání a soudržnosti v našich společnostech naprosto stejně, jako to činil Durkheim u ,primitivư“, a to pomocí technik, jež zahrnují srovnávání dílčích institucí v odlišných kolektivech (at’ už vzájemně vzdálených časem, geografickým prostorem nebo jen výrazně regulovanými kanály pro komunikaci a interakci mezi lidmi v jednom čase a geografickém prostoru). Jinými slovy, nic nám nebrání dělat normální, respektive ne tak úplně normální, ale symetrickou antropo$\operatorname{logii}{ }^{28}$. Součástí úsilí o to, aby byla antropologie symetrická, je i odstranění předpokladu, který byl v Durkheimově práci, jak jsem se pokusil ukázat, ve specifickém smyslu teoreticky nadbytečný, předpokladu, že společnost (australských) „primitivư“ je ze své podstaty náboženská.

Symetričnosti by bylo možné dosáhnout $i$ tím, že bychom za stejně náboženskou považovali i společnost vlastní, a z tohoto hlediska bychom analyzovali např́íklad autoritu vědců, kteří jsou třeba $\mathrm{v}$ Česku ještě stále tak spojeni s nepodmíněnou pravdou, že se mohou těšit $\mathrm{z}$ privilegovaného statusu politicky neutrálních arbitrů ve vztahu $\mathrm{k}$ veřejným problémům (Konopásek 2006). Koneckonců takový narativ „náboženské společnosti“ by byl z povahy toho, že jde o narativ, stejně nevyvratitelný (viz Vido 2011: 10) jako nějaký narativ sekularizace. $\mathrm{O}$ tom, jaké zbytečné zmatky, praktické komplikace, nejasnosti i násilí s sebou pojem náboženství nese, již bylo řečeno dost na to, aby bylo zřejmé, proč je lepší jak pojem náboženství, tak všechny možné narativy, které by okolo něj šlo vystavět, včetně narativů sekularizace, úplně opustit. Získáme tím př́slib, který možná nezní př́iliš ambiciózně, ale je otázka, zda si můžeme smysluplně přát něco víc:

[M]ísto abychom poskytovali základ něčemu již existujícímu, místo abychom doplňovali načrtnuté linie do plných tvarů, místo abychom se uklidňovali tímto návratem a konečným potvrzením, místo abychom završovali tento št’astný kruh, který nám po bezpočtu úskoků a po tolika probdělých nocích dává na vědomí, že vše je zachráněno, budeme se muset odvážit za hranice důvěrně známých krajin, vzdát se navyklých záruk, vstoupit na ještě nezmapované území a jít vstříc cíli, který není snadné předvídat. (Foucault 2002: 63)

\section{Literatura}

ASAD, Talal. The Construction of Religion as an Anthropological Category. In: ASAD, Talal. Genealogies of Religion: Discipline and Reasons of Power in Christianity and Islam. Baltimore: John Hopkins University Press, 1993, s. 27-54. ISBN 0801846323.

28 Pojmem „normální“ ve vztahu k antropologii odkazuji k tomu, že antropologie se etablovala v kontextu kolonialismu, což mělo za následek, že př́liš symetrická nebyla (viz Wallerstein 1998). Pojmem „symetrická“ antropologie samozřejmě narážím na výše rozebíraný princip symetrie a v souvislosti s tím na Latourovu představu ,antropologie, která se vrací z tropư “ ve chvíli, kdy přestaneme být moderní (Latour 1993: 100-103). 
ASAD, Talal. What Might an Anthropology of Secularism Look Like? In: ASAD, Talal. Formations of the Secular: Christianity, Islam, Modernity. Stanford: Stanford University Press, 2003, s. 21-66. ISBN 0804747679.

BERGER, Peter L. The Sacred Canopy: Elements of a Sociological Theory of Religion. 2nd ed. New York: Doubleday, 1990 [1967]. ISBN 0385073054.

BERGER, Peter. Vzdálená sláva: hledání víry ve věku lehkověrnosti. Brno: Barrister \& Principal, 1997. ISBN 8085947188.

BHABHA, Homi. Introduction. In: BHABHA, Homi. The Location of Culture. London: Routledge, 2004 [1994], s. 1-27. ISBN 0415336392.

BLOOR, David. Knowledge and Social Imagery. 2nd ed. Chicago: University of Chicago Press, 1991 [1976]. ISBN 0226060977.

BOYER, Pascal. Religion Explained: The Evolutionary Origins of Religious Thoughts. New York: Basic Books, 2001. ISBN 0465006965.

BRUCE, Steve. God is Dead: Secularization in the West. Malden: Blackwell Publishing, 2002. ISBN 0631232753.

CHOUDHURI, Nirad C. Hinduism: A Religion to Live By. New Delhi: Oxford University Press, 1979 (citováno podle reprintu v The Hinduism Omnibus. 2nd ed. New Delhi: Oxford University Press, 2003. ISBN13 9780195664119).

DAVIEOVÁ, Grace. Výjimečný prípad Evropa: podoby virry v dnešním světě. Brno: Centrum pro studium demokracie a kultury, 2009. ISBN 9788073251925.

DOBBELAERE, Karel. Secularization: An Analysis at Three Levels. Brussels: Peter Lang, 2002. ISBN 9052019851.

DOUGLAS, Mary. Purity and Danger: An Analysis of the Concepts of Pollution and Taboo. 1st ed. 2nd reprint. London: Routledge, 1992 [1966]. ISBN 0415066085.

DOUGLAS, Mary. Natural Symbols: Explorations in Cosmology. 2nd ed., 4th reprint. London: Routledge, 2010 [1970]. ISBN10 0415314542.

DÜLMEN van, Richard. Historická antropologie: vývoj - problémy - úkoly. Praha: Dokořán, 2002. ISBN 8086569152.

DURKHEIM, Émile. Les formes élémentaires de la vie religieuse: Le système totémique en Australie [on-line]. Paris: Les Presses universitaires de France, 1968 [cit. 2. 10. 2013]. Dostupné z: http:// classiques.uqac.ca.

DURKHEIM, Émile. Elementární formy náboženského života: systém totemismu v Austrálii. Praha: Oikoymenh, 2002. ISBN 8072980564.

DURKHEIM, Émile. Společenská dělba práce. Brno: Centrum pro studium demokracie a kultury, 2004. ISBN 8073250411.

FITZGERALD, Timothy. A Critique of „Religion“ as a Cross-Cultural Category. Method \& Theory in the Study of Religion. 1997, roč. 9, č. 2, s. 91-110. ISSN 0943-3058.

FITZGERALD, Timothy. Playing Language Games and Performing Rituals: Religious Studies as Ideological State Apparatus. Method \& Theory in the Study of Religion. 2003, roč. 15, č. 3, s. 209-254. ISSN 0943-3058.

FOUCAULT, Michel. Archeologie vědění. Praha: Herrmann \& synové, 2002. ISBN 8023901249.

FUJDA, Milan. Modernizace, nová religiozita a akulturace hinduismu v českém okultismu. Sociální studia. 2008a, roč. 5, č. 3-4, s. 137-152. ISSN 1214-813X.

FUJDA, Milan. Individualizace, detradicionalizace a moderní religiozita: okultismus jako důsledek a projev modernizačních změn. Religio. Revue pro religionistiku. 2008b, roč. 16, č. 1, s. 57-85. ISSN 1210-3640.

FUJDA, Milan. Akulturace hinduismu a formování moderní religiozity: k sociálním dějinám českého okultismu 1891-1941. Praha: Malvern, 2010a. ISBN 9788086702810. 
FUJDA, Milan. Bouře ve sklenici vody? K několika nejasnostem ohledně povahy „skutečného“, „konstruovaného“ a „redukcionismu“. Biograf. 2010b, č. 52-53, s. 67-74. ISSN 1211-5770.

HANEGRAAFF, Wouter J. Introduction: The Birth of a Discipline. In: FAIVRE, Antoine a Wouter J. HANEGRAAFF, eds. Western Esotericism and the Science of Religion. Leuven: Peeters, 1998a, s. VII-XVII. ISBN 9042906308.

HANEGRAAFF, Wouter J. New Age Religion and Western Culture: Esotericism in the Mirror of Secular Thought. 2nd ed. New York: State University Press, 1998b. ISBN 9004106960.

HANEGRAAFF, Wouter J. New Age Religion and Secularization. Numen. 2000, roč. 47, č. 3, s. $288-312$. ISSN 0029-5973.

HORSKÝ, Jan. Dějepisectví mezi vědou a vyprávěním: úvahy o povaze, postupech a mezích historické vědy. Praha: Argo, 2009. ISBN 9788025701249.

HRUSTIČ, Tomáš. Náboženské konverzie Rómov vo východnom Zemplíne - prípadová štúdia ret’azových konverzií. In: GREŠKOVÁ, Lucia, ed. Pastorácia Rómov (hl'adanie rómskeho Boha). Bratislava: Ústav pre vzt'ahy štátu a cirkví, 2009, s. 123-142. ISBN 9788089096398.

HRUSTIČ, Tomáš. Social Change and Some Other Factors of Religious Conversion among Roma in Eastern Slovakia. In: KOVÁČ, Milan a Tomáš GÁL, eds. Religious Change. Bratislava: Chronos, 2010, s. 125-129. ISBN 8089027156.

KING, Richard. Orientalism and Religion: Postcolonial Theory, India and 'the Mystic East'. London: Routledge, 1999. ISBN 9780415202589.

KNORR CETINA, Karin. Epistemic Cultures: How the Sciences Make Knowledge. Cambridge (MA): Harvard University Press, 1999. ISBN 0674258940.

KONOPÁSEK, Zdeněk. Why Experts Are Seen as Neutral Arbiters in the Czech Republic? Understanding the Post-Communist Politics of De-Politicization CTS Research Reports, CTS-06-06 [online]. Praha: CTS, 2006 [cit. 14.04.2013]. Dostupné z: http://www.cts.cuni.cz/soubory/reporty/ CTS-06-18.pdf.

KONOPÁSEK, Zdeněk. V čem spočívá pravda náboženské skutečnosti? Sociologický pohled na mariánská zjevení a démonické posedlosti. Biograf. 2010, č. 52-53, s. 89-101. ISSN 1211-5770.

KONOPÁSEK, Zdeněk a Jan PALEČEK. V moci d'ábla: exorcismus věřícnýma očima. Biograf [online]. 2006, č. 40-41, 75 odst. [cit. 18.04.2011]. ISSN 1211-5770. Dostupné z: http://www.biograf.org/ clanky/clanek.php?clanek=4006.

KONOPÁSEK, Zdeněk a Jan PALEČEK. The Principle of Symmetry From the Respondents' Perspective: Possessions, Apparitions and Mental Illnesses in Research Interviews With Clerics. Forum Qualitative Sozialforschung / Forum: Qualitative Social Research [online]. 2011, roč. 12, č. 1, čl. 12, 74 odst. [cit. 12.04.2012]. ISSN 1438-5627. Dostupné z: http://nbn-resolving.de/urn:nbn:de:0114-fqs1101129.

KONOPÁSEK, Zdeněk a Jan PALEČEK. Apparitions and Possessions as Boundary Objects: An Exploration Into Some Tensions Between Mental Health Care and Pastoral Care. Journal of Religion and Health. 2012, roč. 51, č. 3, s. 970-985. ISSN 1573-6571.

KRCHA, Martin. Z šera ne-jasného. Biograf. 2010, č. 52-53, s. 83-87. ISSN 1211-5770.

LATOUR, Bruno. We Have Never Been Modern. Cambridge (MA): Harvard University Press, 1993. ISBN 0674948394.

LATOUR, Bruno. On Recaling ANT. In: LAW, John a John HASARD, eds. Actor Network Theory and After. Oxford: Blackwell Publishing and The Sociological Review, 1999, s. 15-24. ISBN 0631211942.

LATOUR, Bruno. Když věci vracejí úder: co mohou sociálním vědám přinést „vědní studia“. Biograf [online]. 2002, č. 29, 41 odst. [cit. 18.04.2011]. ISSN 1211-5770. Dostupné z: http://www.biograf. org/clanky/clanek.php?clanek=2901.

LATOUR, Bruno. Reassembling the Social: An Introduction to Actor-Network-Theory. Oxford: Oxford University Press, 2005. ISBN 9780199256044. 
LAW, John. Organizing Modernity. Oxford: Blackwell, 1994. ISBN 0631185135.

LUCKMANN, Thomas. The Invisible Religion. New York: Macmillan, 1967. ISBN-10: 0025767003.

MARTIN, Luther H. a Donald WIEBE. Religious Studies as a Scientific Discipline: The Persistence of a Delusion. Religio. Revue pro religionistiku. 2012, roč. 20, č. 1, s. 9-18. ISSN 1210-3640.

McCUTCHEON, Russel T. Manufacturing Religion: The Discourse on Sui Generis Religion and the Politics of Nostalgia. New York: Oxford University Press, 2003. ISBN 0195166639.

McGREGOR, R. S., ed. The Oxford Hindi-English Dictionary. 20th reprint. New Delhi: Oxford University Press, 2005. ISBN13 9780195638462.

MICHAELS, Axel. Hinduism: Past and Present. New Delhi: Oriental Longman, 2005. ISBN 8125027769.

MILLS, Charles W. Sociologická imaginace. 2. vyd. Praha: Sociologické nakladatelství, 2008. ISBN 9788086429939.

MONIER-WILLIAMS, Monier. Sanskrit-English Dictionary. New Delhi: Munishram Manoharlal, 2004. ISBN 8121502004.

ONDRAŠINOVÁ, Michaela. Jak uchopit „neuchopitelné“: diskuse o detradicionalizované spiritualitě. In: LUŽNÝ, Dušan a David VÁCLAVÍK, eds. Individualizace náboženství a identita: poznámky k současné sociologii náboženství. Praha: Malvern, 2010, s. 118-142. ISBN 9788086702698.

PALEČEK, Jan. Mariánský zázrak ve světle sociologie, sociologie ve světle slunečního zázraku. Biograf. 2010, č. 52-53, s. 41-66. ISSN 1211-5770.

PALEČEK, Jan. Kde všude jsou lvi? Biograf [online]. 2011, č. 54, 11 odst. [cit. 02.04.2012]. ISSN 12115770. Dostupné z: http://www.biograf.org/clanky/clanek.php?clanek=5409.

SAID, Edward W. Orientalism. 2nd reprint. London: Penguin Books, 1995 [1978]. ISBN 0140238670.

SLÁDEK, Ondřej. Hermeneutická imaginace Mircei Eliada. Religio. Revue pro religionistiku. 2006, roč. 14, č. 2, s. 147-172. ISSN 1210-3640.

SPUNAR, Pavel. Napětí mezi oficiálním a „lidovým“ náboženstvím ve středověku. In: BĚLKA, Luboš a Milan KOVÁČ, eds. Normativní a žité náboženství. Brno - Bratislava: Masarykova univerzita a Chronos, 1999, s. 90-102. ISBN 8021020474.

STAMM, Hugo. Pozor esoterika: mezi spiritualitou a pokušením. Praha: Academia, 2002. ISBN 8020010181.

TÍŽIK, Miroslav. Oslepený žiarou slnka: kritika kritiky sociológie náboženstva. Biograf. 2010, č. 52-53, s. 75-82. ISSN 1211-5770.

TOMASELLI, G. Keyan a Arnold SHEPPERSON. „Speaking in Tongues, Writing in Vision“: Orality and Literacy in Televangelistic Communications. In: HOOVER, Steward M. a Lynn S. CLARK, eds. Practicing Religion in the Age of the Media: Explorations in Media, Religion, and Culture. New York: Columbia University Press, 2002, s. 345-359. ISBN 0231120893.

VIDO, Roman. Konec velkého vyprávění? Sekularizace v sociologické perspektivě. Brno: Centrum pro studium demokracie a kultury, 2011. ISBN 9788021057890.

WALLERSTEIN, Immanuel, ed. Kam směřuji sociální vědy: zpráva Gulbenkianovy komise o restrukturaci sociálních věd. Praha: Sociologické nakladatelství, 1998. ISBN 8085850656.

WHITE, Robert A. Religion and Media in the Construction of Cultures. In: HOOVER, Stewart M. a Knut LUNDBY, eds. Rethinking Media, Religion, and Culture. Thousand Oaks: SAGE, 1997. ISBN 0761901701.

ZBÍRAL, David. Ve dva bohy věriti nebudeš: konstruování „katarského dualismu“ v inkvizičních registrech. Religio. Revue pro religionistiku. 2007, roč. 15, č. 1, s. 29-46. ISSN 1210-3640.

ZBÍRAL, David. Označení, typologie a genealogie středověkých herezí: inspirace a výzvy pro teorii religionistiky. Religio. Revue pro religionistiku. 2010, roč. 18, s. 2, s. 163-190. ISSN 1210-3640.

ZBÍRAL, David. Osobní religiozita, náboženství a členství: případ Armanna „Pungilupa“ z Ferrary. Religio. Revue pro religionistiku. 2011, roč. 19, č. 2, s. 147-178. ISSN 1210-3640. 


\section{Autor}

Milan Fujda přednáší na Ústavu religionistiky Filozofické fakulty Masarykovy univerzity v Brně. Zabýval se akulturací hinduismu v českém okultismu jako otázkou, na jejímž základě objasňoval formování moderní individuální detradicionalizované religiozity. Postupně s tím, jak opouští pojem náboženství, přesouvá svou pozornost k problematice identity, autority a vědění v sociálních interakcích.

Kontakt:milky@mail.muni.cz 